\title{
THE RELATIONAL ECOLOGY OF IDENTIFICATION: HOW ORGANIZATIONAL IDENTIFICATION EMERGES WHEN INDIVIDUALS HOLD DIVERGENT VALUES
}

\author{
MARYA L. BESHAROV \\ Cornell University
}

\begin{abstract}
This research builds on theory about how identification develops when members differ in which organizational values they hold to be important. It is relatively well established that conflict and dis-identification arise under such conditions. In the socially responsible retail company I studied, in contrast, I found identification as well as dis-identification. Both outcomes emerged from members' interactions with others whose values and behaviors differed from their own. Identification arose when managers interpreted and enacted organizational values for frontline employees by developing integrative solutions, removing ideology, and routinizing ideology. Dis-identification developed in the absence of these practices. The resulting process model suggests a relational ecology of identification, in which identification emerges from the combination of bottom-up interactive processes among organizational members and top-down interpretations and enactments by managers. This model advances understanding of the relational dynamics of identification, offers new insight into how organizations can benefit from multiple identities, and illuminates the double-edged sword of ideology in organizations.
\end{abstract}

Extant research provides strong evidence of the central role that identification plays in organizational action (Albert, Ashforth, \& Dutton, 2000). Identification occurs when members perceive their own identity to overlap with their organization's identity, leading them to define themselves in terms of the organization and place a high value on organizational membership (Ashforth \& Mael, 1989; Ashforth, Harrison, \& Corley, 2008; Dutton, Dukerich, \& Harquail, 1994). Research has shown that identification is positively associated with organizational citizenship behaviors, work effort, and cooperation (Bartel, 2001; Dukerich, Golden, \&

I would like to thank Associate Editor Adam Grant for his guidance throughout the review process, as well as three anonymous reviewers for their constructive feedback and suggestions. I also wish to acknowledge the comments and advice received on earlier versions of this manuscript from Michel Anteby, Shelley Brickson, Diane Burton, Robin Ely, Richard Hackman, Peter Marsden, Kathleen McGinn, Lisa Nishii, Siobhan O’Mahony, Mike Pratt, Wendy Smith, Spela Trefalt, and Michele Williams, as well as participants in the ILR writing group and the May Meaning Meeting. I thank Bhadrinath Vaidhyanathan for his research assistance. Finally, I am indebted to the employees and managers at Natural Foods for sharing their time and experience.
Shortell, 2002; Mael \& Ashforth, 1992; O’Reilly \& Chatman, 1986), as well as organizational commitment (Foreman \& Whetten, 2002) and lower turnover (Mael \& Ashforth, 1995). Other studies have linked identification with helping behaviors and social support, information sharing, job satisfaction, creativity, and organizational control (Ashforth et al., 2008). In all these ways, identification leads to behaviors that help organizations accomplish their objectives.

However, the benefits of identification are much more elusive when members differ in which attributes of an organization's identity they hold to be important. Identity attributes are the values, goals, beliefs, traits, and abilities that constitute an organization's central, enduring, and distinct features (Ashforth et al., 2008). Even organizations with relatively coherent identities have multiple and potentially conflicting values that form the basis of their identity (Gioia, 1998; Kreiner \& Ashforth, 2004). Indeed, in their seminal work on organizational identity, Albert and Whetten (1985) argue that, over time, many if not most organizations develop identities that include incompatible attributes. In such situations, tensions may emerge between sub-groups associated with divergent values (Ashforth \& Reingen, in press; Pratt \& Rafaeli, 1997). Conflict also often arises within individuals, 
who grapple with how to resolve contradictory implications for action that stem from different organizational values (Golden-Biddle \& Rao, 1997). Ultimately, mutual dis-identification and intractable conflict can emerge (Glynn, 2000), and organizational performance suffers (Battilana \& Dorado, 2010).

Given the prevalence of divergent values within organizations and the challenges this poses for identification, it is critical to understand how identification emerges when members differ in which organizational values they hold to be important. Existing research, however, has either focused on how multiple identity attributes manifest and are managed at the organizational level (e.g., Clark, Gioia, Ketchen, \& Thomas, 2010; Pratt \& Foreman, 2000; Pratt \& Kraatz, 2009), or has emphasized the potential for conflict and mutual dis-identification among members (e.g., Glynn, 2000; Golden-Biddle \& Rao, 1997; Pratt \& Rafaeli, 1997). We know less about the processes through which identification emerges when members hold different organizational values to be important. I seek to address this gap. To do so, I draw on a qualitative, inductive study of a socially responsible retail company, "Natural Foods" (a pseudonym), whose identity includes economic values of profit and growth, as well as societal values of environmental sustainability, health, and community welfare.

My analysis of Natural Foods illuminates how identification can emerge in the presence of divergent values and behaviors among members. This occurs when managers who hold both economic and societal values to be important interpret and enact these values for frontline employees through practices of developing integrative solutions, routinizing ideology, and removing ideology. In contrast, dis-identification arises in the absence of these practices. The model that emerged from these findings expands understanding of how relational processes among members influence identification, and shows how these bottom-up dynamics are connected to top-down identification management strategies. It also offers new insight into how organizations can benefit from multiple identities, and into the role of ideology in organizations.

\section{ORGANIZATIONAL IDENTITY AND MEMBER IDENTIFICATION}

Two streams of research are relevant for understanding how identification emerges when members differ in which organizational values they hold to be important. The first stream focuses on the nature and management of organizational identity. Organizational identity refers to the central, enduring, and distinct features of an organization that differentiate it from other organizations (Albert \& Whetten, 1985; Whetten, 2006). Identity scholars have long recognized that organizational identities include multiple, and sometimes incompatible, attributes (Albert \& Whetten, 1985; Dutton \& Dukerich, 1991; Gioia, 1998; Pratt \& Foreman, 2000). This can occur when organizations take on the characteristics of more than one organizational form, adopt multiple and inconsistent goals, or make incompatible commitments to different stakeholder groups (King, Felin, \& Whetten, 2010; Kraatz \& Block, 2008; Whetten, 2006). It can also occur when members' shared sense of what is central, enduring, and distinct about their organization includes inconsistent attributes (Gioia, Schultz, \& Corley, 2000: 74; Golden-Biddle \& Rao, 1997), or when members disagree about which attributes are central, enduring, and distinct (Glynn, 2000; Pratt \& Rafaeli, 1997).

Empirical examples of such "multiple identity" organizations (Pratt \& Foreman, 2000) abound. In the non-profit sector, research universities (Albert \& Whetten, 1985), symphony orchestras (Glynn, 2000), cooperatives (Foreman \& Whetten, 2002), hospitals (Pratt \& Rafaeli, 1997), and other healthcare organizations (Dukerich et al., 2002) have identities that combine societal values emphasizing cultural or ideological principles with economic values. For example, Dukerich et al. (2002) find that physicians described the healthcare organizations with which they were affiliated as having values as varied as compassionate and aggressive, stable and constantly changing, and committed to employee well-being as well as being concerned with the bottom line. Public sector organizations also frequently incorporate multiple values into their identities (e.g., Dutton \& Dukerich, 1991). In the last several decades, identities that combine divergent values have become common in the forprofit sector as well, with the rise of business organizations that explicitly address social and environmental problems (Hoffman, Badiane, \& Haigh, 2012; Margolis \& Walsh, 2003; Smith, Gonin, \& Besharov, 2013). Even traditional corporations increasingly have identities that include multiple and potentially contradictory values, as they operate in global markets, incorporate a diverse employee population, and engage in exploration of new products alongside exploitation of existing products (Smith \& Lewis, 2011). 
In addition to providing strong evidence of the prevalence of organizations with multiple and potentially conflicting values, research on organizational identity has shed light on how these different attributes of an organization's identity can be managed and potentially unified. Pratt and Foreman (2000) suggest appropriate management strategies depend on the number of different attributes and on the synergies between them. Pratt and Corley (2007) build on this framework by considering how different identity management strategies create benefit or harm for individual members, although they do not consider the effect of these management strategies on members' identification. Other studies focus specifically on how organizations can combine multiple identity attributes into a single overarching identity. Clark and colleagues (Clark et al., 2010) show how the creation of a "transitional identity" enabled two merged organizations to unify their previously distinct identities. In a similar vein, Pratt and Kraatz (2009) introduce the concept of an "organizational self" to explain how organizations with multiple identity attributes can integrate them into a coherent whole. Taken together, the studies within this first stream of research offer valuable insights into how multiple identity attributes emerge at the organizational level. Research within this stream also illuminates organizational practices and processes through which multiple identity attributes can be managed. However, this research tells us little about the implications that multiple identity attributes have for individual members and, in particular, for members' identification with their organization.

The second stream of research that is relevant focuses on identification among individuals who differ in which organizational values they hold to be important. This work emphasizes negative consequences of divergent values, but does not explain how identification can emerge in such a context. As noted above, identification occurs when individuals define themselves in terms of the central, enduring, and distinct features of their organization (Dutton et al., 1994; Pratt, 1998), leading them to place a high value on organizational membership (Ashforth et al., 2008). Identification scholars recognize that the content involved in members' identification-both the content of one's self-identity and that of the organization's identity - can vary, even within a single organization or collective (Brickson, 2013; Elsbach \& Cable, 2012; Foreman \& Whetten, 2002; Kreiner \& Ashforth, 2004). Other research suggests that when members hold differ- ent identity content (e.g., different values) to be important, conflict and tension are rampant (Fauchart \& Gruber, 2011; Golden-Biddle \& Rao, 1997; Pratt \& Rafaeli, 1997) and organizational performance suffers (Anteby \& Wrzesniewski, 2014; Battilana \& Dorado, 2010; Voss, Cable, \& Voss, 2006). In her study of a symphony orchestra, for example, Glynn (2000) finds that musicians identified with the organization's artistic values, while administrators identified with its economic values. When salary negotiations highlighted these differences, conflict erupted and ultimately became intractable, resulting in a musicians' strike and, later, the forced resignation of the music director.

A few studies offer suggestions for how organizations or individual members might be able to address the challenges that arise when members hold different organizational values to be important. Fiol, Pratt, and O'Connor (2009) develop a model for overcoming intractable identity conflict. However, their theorizing focuses on how to overcome conflict between sub-groups once it has become intractable, not on ongoing work practices and behaviors that enable members to develop and maintain positive organizational identification. Elsbach (2001) and Gutierrez, Howard-Grenville, and Scully (2010) examine coping strategies adopted by individuals within multiple identity organizations, showing that members use "schizo" or "split" identification to maintain positive self-identities even as they dis-identify with some attributes of their organization. These two studies shed light on how members preserve a positive sense of self in organizations whose values they do not entirely share, but they tell us little about the processes through which members come to positively identify with such organizations. Thus, while this second stream of research makes it clear that identification based on divergent values creates challenges for organizations and their members, much less is known about the processes through which identification develops in the face of these challenges.

In summary, prior research has either focused on how divergent values manifest and can be managed at the organizational level, or has emphasized the potential for conflict and dis-identification to erupt when members differ in which organizational values they hold to be important. However, the process through which identification emerges in such situations remains poorly understood. The purpose of this study, therefore, is to expand insight into identification by building theory about how iden- 
tification emerges when members differ in which organizational values they hold to be important.

\section{RESEARCH SETTING AND METHOD}

My exploration of identification based on divergent values is grounded in a qualitative, inductive study of frontline employees and managers at Natural Foods, a socially responsible retail company. A qualitative, inductive approach was appropriate because my goal was to build theory about a phenomenon that is not well explained by the existing literature (Edmondson \& McManus, 2007; Pratt, 2009) - in this case, the phenomenon of identification based on divergent values. Natural Foods represents an extreme case of identification based on divergent values. Extreme cases are useful for developing theory because the dynamics being studied are more visible than they would be in other settings (Eisenhardt, 1989). First, Natural Foods' identity includes economic values of profit and growth, as well as societal values of environmental sustainability, health, and community welfare. As described below, I found that members for whom only economic values were highly important and those for whom only societal values were highly important held competing beliefs about how to be cooperative and help Natural Foods succeed. Behaviors that one member believed to be cooperative were sometimes interpreted by another member as unimportant, counterproductive, and even morally wrong. Second, despite these differences, Natural Foods did not experience intractable conflict or low performance. Indeed, the company grew steadily since its founding in the late 1970s, held an initial public offering in the early 1990s, and continued to expand during and beyond the time of my data collection. Together, these factors make Natural Foods an excellent setting for developing theory about how identification emerges in the presence of divergent values.

\section{Data Collection}

I conducted a pilot study at two Natural Foods stores in the northeast United States, collecting interview data $(n=21)$ to develop a preliminary understanding of the company's identity and the attributes of this identity that members valued. Data for the main study, which was collected over a 15 -month period, consisted of interviews $(n=92)$ and observations (174 hours) from eight additional stores located in the northeast region of the United
States. These stores were selected based on purposive criteria (Miles \& Huberman, 1994) related to the emphasis placed on Natural Foods' societal and economic values. Five to ten years before I collected my data, Natural Foods acquired two regional grocery chains: one that resembled a cooperative and one that more closely resembled a conventional supermarket. The pilot study and early interviews for the main study indicated the identities of these acquired companies, which respectively emphasized societal and economic values, were still evident in the stores. In addition to these acquired sites, Natural Foods had opened new stores with identities that were more balanced in their emphasis on societal and economic values. In order to capture this variation, I composed the sample to include three former "coop" stores, two former "conventional" stores, and three newly built Natural Foods stores. Data collection proceeded sequentially across the eight sites and, within each site, I conducted interviews and observations over the same time period. I collected more data at the first site than at subsequent sites because I wanted to gain an in-depth understanding of the identity dynamics within one store before proceeding to additional stores. I stopped collecting data once theoretical saturation had been reached (Strauss \& Corbin, 1998).

Interviews. I conducted 92 semi-structured interviews with Natural Foods employees and managers. Interviewees were identified from employee lists provided to me by store managers. In selecting interviewees, I used two purposive sampling criteria (Miles \& Huberman, 1994). First, because managers have more responsibility for the organization's business operations, I expected they might place greater importance on Natural Foods' economic values. In order to examine the implications this could have for developing identification, I composed the interview sample to include roughly equal numbers of managers $(n=47)$ and non-managers $(n=44)$. Second, because the pilot study and initial interviews for the main study suggested members of different departments differed in which organizational values they held to be important, I also constructed the interview sample to include members from each of the 11 departments in each store-administration (e.g., accounting, marketing) $(n=12)$, bakery $(n=7)$, customer service $(n=17)$, grocery $(n=9)$, meat $(n=5)$, prepared foods $(n=11)$, produce $(n=9)$, seafood $(n=$ $2)$, specialty (e.g., cheese, chocolates) $(n=5)$, and nutrition $(n=5)$-in addition to at least one store 
manager or assistant store manager at every store ( $n=10$ ). Tenure among the interviewees ranged from a low of one month to a high of 20 years, with an average of 5.8 years and a standard deviation of 5.1 years. $54 \%$ of interviewees were female. Interviews took place on store premises, typically in an empty office or conference room, and they lasted between 30 and 80 minutes each. I used a semistructured protocol covering prior experience, reasons for joining Natural Foods, daily work activities, organizational mission and values, personal interests and values, and future professional plans. All interviews were tape recorded and transcribed. In reporting the interview data, I identify participants by assigning them a number between 1 and 92 and include the prefix $\mathrm{E}$ for employee and $\mathrm{M}$ for manager.

Observation. I engaged in 174 hours of nonparticipant observation. I used these data to contextualize the interview accounts and provide a richer framework in which to understand the management of identification at Natural Foods. In particular, the observation data enabled me to understand members' behavior and the practices through which Natural Foods mitigated conflict and fostered identification. I observed up to three department manager meetings and one to four storewide meetings at each site. ${ }^{1}$ Department manager meetings were held bimonthly and were approximately two hours long. One hour store meetings were held every four to six weeks, and were mandatory for all store employees. I also observed group interview sessions in which four manager candidates were interviewed, one at a time, by a group of 10 employees and managers. In addition, I observed employees and managers on the floor as they interacted with customers, stocked shelves, and performed other duties, as well as in back areas off-limits to customers.

Archival data. I supplemented the interview and observation data with archival data on Natural Foods' history, store operations, employee policies, and stated mission and values. Much of this information was publicly available on the company's website. A few documents were provided by Natural Foods managers, such as the company's employee handbook, as well as evaluation forms and criteria used to assess store and department performance. In addition to providing background information on the company, the archival data offered

\footnotetext{
${ }^{1}$ At one of the eight sites, observation of department manager meetings was not permitted.
}

insight into practices that fostered identification. I initially identified these practices through interviews and observation, and then used the archival data to verify and add detail to my understanding.

\section{Data Analysis}

Consistent with the tenets of grounded theory, I started to analyze the data as I collected it, iterating back and forth between the data and the emerging theoretical arguments (Glaser \& Strauss, 1967; Strauss \& Corbin, 1998; see also Suddaby, 2006). The analysis involved three major steps (see Pratt, Rockmann, \& Kaufmann, 2006), in which I categorized raw data into empirical themes, abstracted and consolidated empirical themes into conceptual categories, and aggregated conceptual categories into a theoretical framework that explains the process of managing identification based on divergent values. These steps are described below and summarized in Figure 1, which connects empirical themes to conceptual categories and shows how the categories aggregate into theoretical dimensions. Throughout the analysis process, I used the ATLAS.ti research software to record, group, and re-group codes, as well as to compare and contrast codes across documents. I also repeatedly returned to the literature to ground my emerging interpretation of the data in existing theories of identification and value conflict.

Step 1: Identifying empirical themes. In step one, I sought to develop first-order codes that describe dominant empirical themes using language that was as close to the data as possible (Strauss \& Corbin, 1998). As themes emerged, I compared them within and across transcripts and field notes in order to refine the boundaries of each one. Once a stable set of themes had emerged, I went back through all relevant passages of the transcripts and field notes to see if they fit the themes. When they did not, the coding scheme was revised. Two early themes concerned what members valued about Natural Foods. Statements reflecting these themes came from many different parts of the interviews, but they most frequently occurred in response to questions about the company's mission and values, and their meaning to the respondent. I initially created the themes of "importance of Natural Foods' values of health, community welfare, and/or environmental sustainability" and "importance of Natural Foods' values of growth and profits" to reflect what members valued about Natural Foods. As I compared statements reflecting these themes, a 
FIGURE 1

\section{Overview of Data Structure}

\section{Empirical Themes}

- Importance of NF's societal values of health, community welfare, and environmental sustainability (low to moderate, high)

- Importance of NF's economic values of profit and growth (low to moderate, high)

- Incorporating health, environmental and ethical considerations into operational decisions vs. improving efficiency and financial performance

- Educating customers about health, natural foods, environmental sustainability, and community involvement vs. meeting customer needs (proactive and reactive)

- Promoting products that advance both business and social missions

- Implementing work practices that advance both business and social missions

- Emphasizing “choice” and “service,” not ideological principles, in customer interactions

- Emphasizing taste and quality, not ideological purity, of products

- Developing formal policies and work procedures to implement social mission

- Encouraging member involvement in formal policies and work procedures for implementing social mission

\begin{tabular}{l} 
- Perceiving NF's societal and/or economic values to be upheld \\
welfare, or environmental sustainability over time \\
\hline - Perceiving NF's values of health, community welfare, or \\
- Valuironmental sustainability to be morally violated
\end{tabular}

further distinction arose around the intensity with which members valued these attributes of Natural Foods. I therefore revised these themes to distinguish "low to moderate" from "high" levels of importance. Quotations indicating "low to moderate" importance involved negative statements about the attribute and statements in which the respondent accepted the attribute, but did not indicate it was core to their personal identity or values. Quotations indicating "high" importance involved only positive statements about the attribute, and included
Conceptual Categories Aggregate Theoretical Dimensions
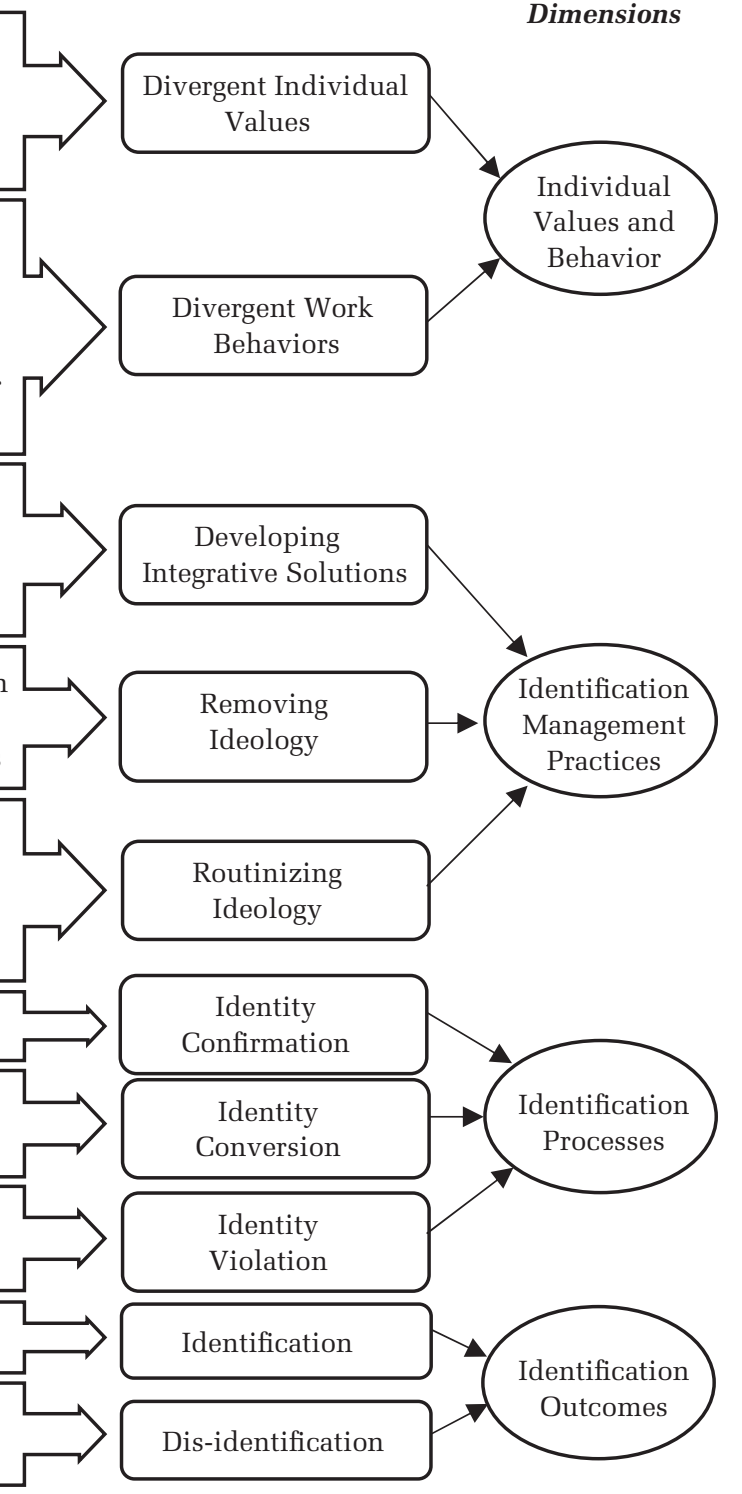

language linking the attribute to the respondent's personal identity or values.

Other themes concerned members' behavior. Data on behavior came primarily from my observation field notes, particularly those on managers. Since there were fewer managers (versus employees) per store and because I had intentionally oversampled managers in my interviews, I had observation data for the majority of managers who were interviewed. I supplemented the manager observation data with self-reports of behavior from the 
interviews. For example, I observed, and members described in their interviews, different types of customer interactions. Some members tended to talk at length with customers about how and why Natural Foods promoted health and environmental sustainability, while others proactively and efficiently helped customers find products. I captured this distinction with the themes "educating customers about health, natural foods, environmental sustainability, and community involvement" and "meeting customer needs." I also observed different approaches to store operations. Some members initiated, became involved in, and promoted sustainability, health, and community initiatives, while others focused on initiatives to improve financial performance. I created the themes "incorporating health, environmental, and ethical considerations into store operations" and "improving efficiency and financial performance" to capture these different behaviors.

Step 2: Constructing conceptual categories. In the second stage of analysis, I used axial coding (Strauss \& Corbin, 1998) to consolidate and abstract empirical themes into higher-level conceptual categories. To do so, I engaged in constant comparison, continually comparing instances of empirical themes in the data to one another and to my emerging conceptual categories (Glaser \& Strauss, 1967; see also Glaser, 2002). As categories emerged, I wrote memos to elaborate the dimensions of these categories and the relationships between them (Miles \& Huberman, 1994; Strauss \& Corbin, 1998). For example, looking at statements about which attributes of Natural Foods members valued led me to combine the themes of "importance of Natural Foods' values of health, community welfare, and/or environmental sustainability" and "importance of Natural Foods' values of growth and profits" into the conceptual category "divergent individual values." Similarly, comparing themes about members' behavior in customer interactions and store operations led me to see that a critical feature of these behaviors was their differences-the fact that members approached the same task in different ways. I therefore consolidated these themes into the category of "divergent work behaviors."

Step 3: Developing a process model. In the final stage of the analysis, I sought to aggregate the conceptual categories into an empirically grounded model that represented the process through which identification emerged in the presence of divergent values. In this stage, I considered the role that the conceptual categories played in the development of identification. Approaching the data from this perspective, I saw that divergent individual values and behaviors formed the starting point for two processes, one leading to identification, the other to dis-identification. Identification emerged when managers engaged in three practices-developing integrative solutions, routinizing ideology, and removing ideology - that confirmed and expanded members' identities. The absence of these practices led to dis-identification.

I took several steps to ensure the trustworthiness of my analysis. First, after my initial coding was complete, a research assistant independently coded the interview transcripts and observation field notes. I provided him with all passages to which I had assigned an empirical theme (with my theme codes removed), then gave him descriptions of the themes and asked him to independently assign a theme to each passage. We compared our coding of passages, discussed disagreements, and adjusted the empirical themes based on these conversations. The research assistant and I repeated this process several times as I refined the theoretical model. Second, I performed "member checks" (see Nag, Corley, \& Gioia, 2007) at several points during the analysis process by describing my findings to store and regional managers, as well as to Natural Foods' CEO. These conversations provided valuable feedback on the emerging framework and helped ensure my interpretations were consistent with the experience of organizational members.

\section{FINDINGS}

\section{Individual Values and Behaviors}

Members understood Natural Foods' identity to include both societal and economic values, but they varied in how important each type of values was to them personally. These differences were reflected in members' work behaviors, particularly between members for whom only societal values or only economic values were important. Below, I detail how members' values and behaviors diverged. Table 1 provides additional supporting evidence.

Divergent individual values. Four different combinations of values were evident among members. First, "idealist" members placed high importance on Natural Foods' societal values of health, natural foods, community, and environmental sustainability, but low to moderate importance on Natural Foods' economic values. Some idealists were health advocates with a deep commitment to 


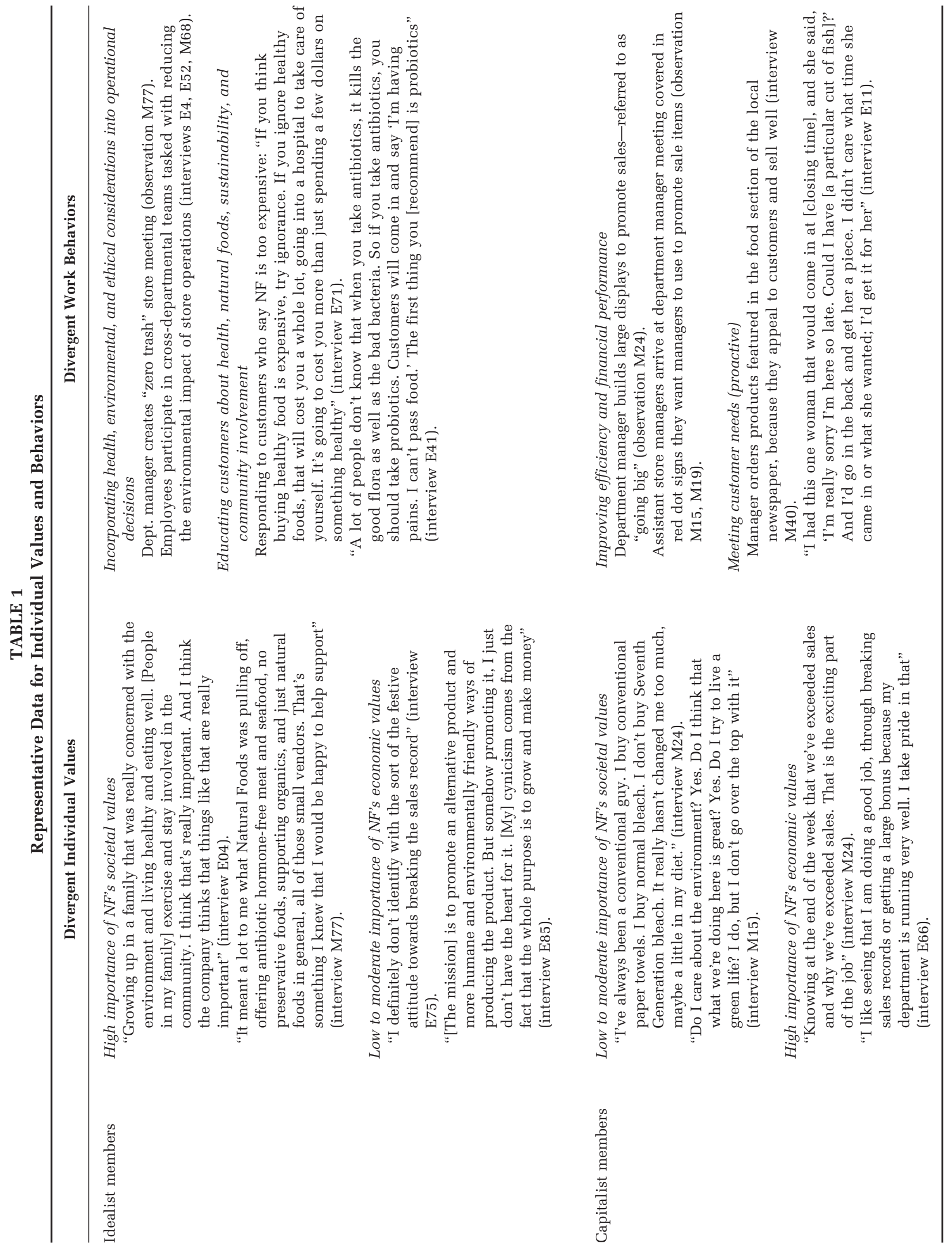




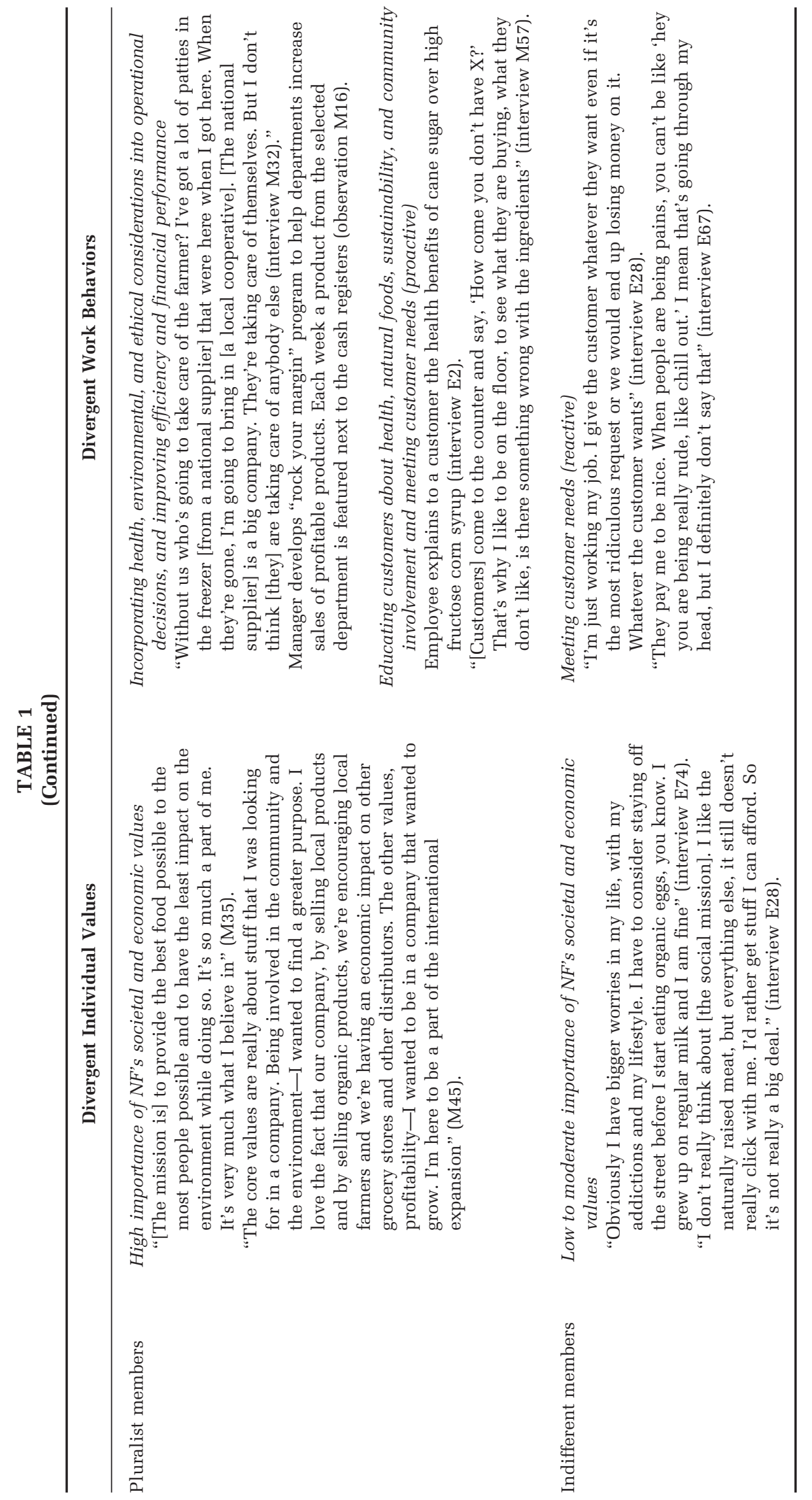


eating and promoting natural, organic, and locally produced food. Others were environmentalists for whom sustainability and green living were of paramount importance, and still others were dedicated to promoting animal rights or supporting local communities. Many represented a combination of these types. For example, an employee explained:

I believe in [Natural Foods'] giving back to the community philosophy, I believe in their environmental philosophy, and I'm a food junkie. It just seemed like a perfect fit for me. At this moment in my life I want to give back. I want to make a mark that leaves this world a better place, and I'm able to do that by being part of this company, and that's really important to me. (E09)

Idealists were often aware of the company's social mission before being hired, and reported it to be one of the main reasons for joining the company. For example, a department manager with a background in natural foods and macrobiotics had sought out Natural Foods because it "was true to my core values and what I was interested in at that time of my life and still today" (M87). Some idealists accepted economic values, but they were not of high personal importance. Admitted one employee: "I might feel differently [if I were in charge], but from the ground level it's like, good for the store, they made more money this week than I am going to make in two years" (E75).

Second, "capitalist" members placed high importance on Natural Foods' economic values of profit and growth but low to moderate importance on societal values. For example, a store manager was excited to work at Natural Foods because he was able and encouraged to help the company make money. "It sounds corny," he admitted, "but it's what [I] wanted to do" (M44). Many capitalists came to Natural Foods from conventional grocery stores and initially had little knowledge of natural foods or environmental sustainability. As another store manager explained:

A lot of us came from conventional markets, and I don't think we bought into the whole natural foods thing at that point. To us it was just sort of the same old thing where you have a job and you've got to make the company profitable. The natural foods aspects of it were secondary to us. I was learning bits here and there. But I have to admit I wasn't that interested. (M91)

Capitalists tended to accept Natural Foods' social mission, but the values on which it was based were not of high personal importance. An assistant store manager explained: "I support recycling and composting. But it's not going to be my entire life, no. I have bigger priorities" (M19).

Third, "pluralist" members placed high importance on both Natural Foods' societal and economic values. A department manager explained:

[The mission] means a lot to me, it is huge for me. I live my life in a way that I can have a positive impact on the environment, on people around me, and [I] try to get back to a more natural way of living. I live in a town that has [made] all its public spaces free. I built a log home from sustainable forests, in order to not have the impact of a conventional home that [emits gases]. It's very important to work for a company that values those things that I value, [that] values people, values the environment, and still values being successful in the world. Because even though I like to have my life as natural as possible, I also like being successful financially and [taking] pride in my work. Working for a company that has those same values is just part of my life. (M88)

Pluralists also tended to perceive societal and economic values as mutually reinforcing, rather than conflicting. In this respect, they can be understood as having a complementary identity structure (Dutton, Roberts, \& Bednar, 2010), similar to individuals high on bicultural identity integration (Benet-Martinez, Leu, Lee, \& Morris, 2002). As a department manager explained:

It all works together, and it's pretty clear. We're here to make money. We're here to make customers happy. We're here to make our employees happy. We're here to be involved in the community. And we're here to sell the best product. [Those core values] are part of my life everyday here. I live them every day. And they're natural. They fit. (M14)

Finally, "indifferent" members placed low to moderate importance on both Natural Foods' societal and economic values. As one employee explained, "I have never really paid too much attention to [the values]. Something like organic food and happy people and making the world a better place, I don't really know" (E78). Another stated:

The company's mission is to provide good organic quality food products and non-organic food products too-basically higher quality food. They also want to make money doing so, and they have an environmental component. I mean, it's a nice place to work for, but their mission doesn't really influence other parts of my life. It doesn't resonate very much with me. (E67) 
As these examples illustrate, indifferent members were often aware of the company's mission and sometimes made positive statements about it. However, the societal and economic values underlying this mission were not personally meaningful or central to their identities. Perhaps not surprisingly, indifferent members tended to be newer employees, with an average tenure of 3.3 years compared to the overall average of 5.8 years.

While I have described the four types of members as conceptually distinct, in practice boundaries between types were sometimes blurry. Idealists for whom economic values were of moderate importance resembled pluralists, as did capitalists for whom societal values were of moderate importance. Similarly, indifferent members for whom either societal or economic values were of moderate importance bordered on idealists and capitalists, respectively, and those for whom both economic and societal values were of moderate importance resembled pluralists. In addition, the types were not static. Members sometimes described their values changing over time. This occurred as managers' enactment of Natural Foods' ideology altered the identity attributes members valued, a process I describe in the section on identity conversion below.

Divergent work behaviors. Differences in values manifest in members' discretionary work behaviors. When members had choices over how to conduct their work, they emphasized the attributes of Natural Foods that were personally important to them. These differences were evident in two areas: store operations and customer interactions. In store operations, idealists focused on carrying out the company's commitment to natural foods, health, community, and the environment, while capitalists focused on promoting profits and growth. One idealist employee went out of her way to obtain a composter for her store long before composting became standard practice across the company (E04). An idealist department manager gave detailed instructions to employees at a storewide meeting about how to recycle and compost waste so the store could achieve a "zero trash" store meeting (food and drinks were routinely provided at meetings). This manager also secured funds to purchase extra compost and recycling bins, and placed the bins in high-traffic areas of the store to make it easier for both customers and employees to reduce waste (M77). Capitalists approached store operations differently. They brought food samples from their departments to share at manager meetings, selecting high-margin items and urging their fellow managers to buy the products by explaining how doing so would help the store financially. They also frequently called attention to financial performance at manager and storewide meetings, proudly announcing that their department had outperformed comparable departments at other Natural Foods stores. In a manager meeting, one capitalist publicly mocked another department for its poor sales and profit record, commenting that with a new assistant manager in place, "hopefully, we can start making some money there" (M40).

Differences between idealist and capitalist members were also evident in customer interactions. Idealists proactively educated customers about the health and environmental benefits of Natural Foods' social mission, and associated products and policies. For example, an idealist employee described guiding customers toward products she deemed healthy and steering them away from those she considered less healthy:

We sell [a particular brand of] jams, jellies, sauces, and chutneys, and they have sugar in them. Even though it's pure, raw cane sugar and not refined sugar, [it is] still sugar. I would [not] recommend to [customers] to buy [that brand], because sugar is not good for you and today people eat too much sugar. I am not saying you have to give it up, but limit it. (E60)

In contrast, capitalists focused on meeting customer needs. Many described this in positive terms, as something they sought out and enjoyed. A department manager explained:

If I see someone standing there, I'll go up to them and say, "Can I help you find something?" Or if I notice that they're reading something, I'll ask, "Do you have any questions on that? Do you need any help?" If they're here to pick up seven things for a recipe, I might show them where all seven are, and they'll thank me because they didn't have to spend an hour trying to find stuff. I'm on the floor and I'm doing tasks, but I'm always looking around for customers. (M46)

Capitalists also emphasized the sales benefits of meeting customer needs. A manager in the specialty department, which sold profitable but not necessarily healthy products, explained:

You might have a customer who says, "I am having this party and I want to get a selection of cheeses." We sell hundreds of different types of cheese, so it is up to us to direct where they go. There are always things they didn't think about that we can convince 
them they need. Something to go with the cheesesdifferent spreads or maybe just another food item like olives or crackers. The idea is always to ask them, "Would you like fries with that" — that type of thing. (M66)

Unlike idealists and capitalists, indifferent members engaged in few behaviors beyond what was formally required, and they interpreted these requirements relatively narrowly (on the distinction between narrow versus broad definitions of in-role behavior, see Morrison, 1994). In this respect, their behavior differed from the more expansive, proactive approaches of idealists and capitalists. In store operations, they rarely worked to improve efficiency and financial performance, or to implement Natural Foods' social mission on their own initiative. In customer interactions, they did not proactively educate customers about the social mission (as idealists did), nor did they seek out customers to help them find products or promote sales (as capitalists did). Instead, indifferent members met customer needs in a limited and reactive fashion, engaging in surface acting (Hochschild, 1983) to present a positive face for customers. As one employee admitted: "I put this smile on my face and I sweet talk [customers] because this is my job, but then the minute they leave I am like ...", and she made a face indicating frustration (E63).

Differences in members' values and behaviors created the potential for conflict and mutual disidentification, particularly between idealists and capitalists. Idealists criticized capitalists for being driven by money, power, and status. A department manager explained:

There are some people who are more a part of the mission. You can feel they are excited to be with the company and help out with community service and talk to customers. Then there are people who are just looking for the sales. They are looking to move up with the company and mean more in the company. I think right now the true foodies are still outnumbering the corporate guys. (M21)
Meanwhile capitalists sometimes regarded idealists as overzealous and unreasonable. As a capitalist manager in the meat department admitted:

I don't want to pick on [the nutrition department], but there are some people over there [who say], "Oh my God he's eating a cheeseburger." [They get very upset] knowing there are dead animals in the [meat] case. I'll be walking through back corridors with my coat on and there is blood all over [from cutting meat] and they are running the other way. (M31)

The potential for conflict was further exacerbated by differences in members' hierarchical position. As shown in Table 2, most idealists and indifferent members were employees, while most capitalists were department and store managers. From the idealists' perspective, capitalists' values and behaviors appeared to be privileged by the organization, making them even more reprehensible. For example, one idealist described with frustration a former department manager who "wouldn't recycle anything. You'd find everything in the trash. He just didn't care, and he would fully admit that he was in this job because of the pay" (M13). Despite this behavior, however, the person in question had been promoted to a regional management position.

In the face of these differences, pluralists served as the glue that held members together, mitigating tensions among them and enabling identification to emerge. Consistent with the importance they placed on both societal and economic values, pluralists' behavior in store operations and customer interactions involved a combination of the behaviors found among capitalist and idealist members. More importantly, most pluralists were managers at either the department or store level (see Table 2), and as managers they interpreted and enacted organizational policies in ways that fostered identification among other members. I detail these practices in the next section.

TABLE 2

Tenure and Position of Interviewees, by Type of Member

\begin{tabular}{|c|c|c|c|c|c|}
\hline & $\boldsymbol{n}$ & Avg. Tenure (yrs) & Store Managers $^{a}$ & Department Managers $^{a}$ & Non-managers \\
\hline Idealist & 32 & 5.6 & 1 & 11 & 20 \\
\hline Capitalist & 16 & 7.9 & 4 & 10 & 2 \\
\hline Pluralist & 24 & 6.9 & 5 & 16 & 3 \\
\hline Indifferent & 20 & 3.3 & 0 & 1 & 19 \\
\hline All employees & 92 & 5.8 & 10 & 38 & 44 \\
\hline
\end{tabular}

\footnotetext{
a Includes assistant managers.
} 


\section{Identification Management Practices}

Pluralist managers' interpretation and enactment of Natural Foods' ideology enabled identification to emerge despite members' divergent values and behaviors. This occurred through three practices: developing integrative solutions, removing ideology, and routinizing ideology. While some of these practices stemmed from formal policies at the regional and corporate levels, it was pluralists' enactment of these policies at the store level that fostered identification. In this respect, pluralists served as local leaders, interpreting organizational policies to create meaning for employees (see Podolny, Khurana, \& Hill-Popper, 2005; Smircich \& Morgan, 1982). Below, I elaborate on how they accomplished this. Table 3 provides additional supporting evidence.

Developing integrative solutions. Consistent with the CEO's, and their own, view that Natural Foods' societal and economic values were mutually reinforcing, pluralist managers emphasized products and work practices that incorporated both types of values. Rather than promoting highly profitable products that were not consistent with the social mission or less profitable items that were consistent with this mission, pluralist managers promoted products that met both social and business criteria. Locally produced products were a common focus. As a pluralist department manager explained, "I pay attention to a lot of the [local] cheeses because we're trying to support local farmers. And I use that a lot in the sales pitch with customers in saying, "You know, if we don't support local farmers, they'll [be put out of business by] Wal-Mart." I try to feature a [local] farm every month and get my team interested in that" (M30).

Pluralist managers also developed integrative approaches to operational issues. The way in which two pluralist store managers implemented a com-

TABLE 3

Representative Data for Identification Management Practices

\begin{tabular}{|c|c|}
\hline Conceptual Categories & Empirical Themes and Representative Data \\
\hline \multirow{7}{*}{$\begin{array}{l}\text { Developing Integrative } \\
\text { Solutions }\end{array}$} & Promoting products that advance both business and social missions \\
\hline & $\begin{array}{l}\text { Store managers encourage department managers to promote local products and help them come up with } \\
\text { ideas for doing so effectively (observation M24, M35, M92). }\end{array}$ \\
\hline & $\begin{array}{l}\text { At storewide meeting, store manager promotes newly available baskets made by artisans in a developing } \\
\text { country; emphasizes to employees that sales of the product will help the artisans and also help the store } \\
\text { make money (observation M92). }\end{array}$ \\
\hline & Implementing work practices that advance both business and social missions \\
\hline & Store manager proposes a region-wide “zero waste” competition as a means of implementing NF’s \\
\hline & $\begin{array}{l}\text { commitment to environmental sustainability. In addition to touting the environmental benefits of the } \\
\text { competition, the manager promotes it as a cost-savings measure (interview and observation M76). }\end{array}$ \\
\hline & $\begin{array}{l}\text { Store manager advocates extensive use of new "red dot" sale signs but, at the request of an employee } \\
\text { concerned about waste, agrees to create only a limited number of the signs and encourages re-use } \\
\text { (observation M92). }\end{array}$ \\
\hline \multirow[t]{6}{*}{ Removing Ideology } & Emphasizing “choice” and “service,” not ideological principles, in customer interactions \\
\hline & $\begin{array}{l}\text { "Customer service is giving people a choice. If our customers want plastic bags, they should be able to get } \\
\text { plastic bags and they shouldn't have to feel bad. A customer shouldn’t be made to feel bad because } \\
\text { they're buying meat. It just should not happen" (interview M34). }\end{array}$ \\
\hline & $\begin{array}{l}\text { Employee thinks customers should use reusable bowls and plates at the salad bar, but she does not } \\
\text { advocate this because "management might have something to say to me. I don't think that's part of the } \\
\text { routine to approach customers" (interview E52). }\end{array}$ \\
\hline & Emphasizing taste and quality, not ideological purity, of products \\
\hline & Ingredient standards altered to allow white flour, coffee, and sugar (interviews E03, M80, M88). \\
\hline & $\begin{array}{l}\text { One suburban store promotes natural marshmallow fluff, another features a large chocolate fountain (store } \\
\text { observation). }\end{array}$ \\
\hline \multirow[t]{6}{*}{ Routinizing Ideology } & Developing formal policies and work procedures to implement social mission \\
\hline & Standards for humane treatment of animals (archival data). \\
\hline & $\begin{array}{l}\text { "Local forager" position established at regional and store levels in order to increase sourcing of local } \\
\text { products (archival data, store observation, interview M80). }\end{array}$ \\
\hline & Encouraging member involvement in formal policies and work procedures for implementing social mission \\
\hline & $\begin{array}{l}\text { To increase participation in voluntary training programs about NF's social mission, store manager allows } \\
\text { trainer to offer prizes to participating employees (observation E03, M92). }\end{array}$ \\
\hline & $\begin{array}{l}\text { To increase involvement in community activities, store managers institute competition to see which store's } \\
\text { employees can sell the most food bank coupons (observation M34, M92). }\end{array}$ \\
\hline
\end{tabular}


pany mandate to hold farmers markets in store parking lots provides an illustration. When the CEO announced that all stores would hold farmers markets in their parking lots, idealists responded enthusiastically. One manager effused: "It's amazing. It's awesome. [The CEO] admitted that it wasn't going to be the best thing for the shareholders, but it's going to be a great thing for the community" (M13). However, capitalists were skeptical, noting that allowing farmers to sell produce outside the store could cannibalize in-store sales in Natural Foods' own produce department. The two pluralist store managers I observed grappling with this issue developed implementation plans that upheld idealists' desire to help farmers and capitalists' desire to enhance profits. One store manager held the markets and simultaneously featured the farmers' produce in prepared food dishes sold inside the store. The other helped capitalists interpret the initiative more positively by emphasizing the boost in image and customer traffic that farmers would bring to the store, even while acknowledging that their presence might hurt sales in the short term. Ultimately, the produce department manager at this store, who had initially complained about the initiative, decided he could profit from the positive image the farmers would promote to customers.

Removing ideology. Even as they developed integrative solutions that incorporated the social mission, pluralist managers discouraged explicit promotion of the ideological principles underlying this mission. Indeed, they actively sought to remove ideology, and ideologically driven behaviors, from day-to-day store operations. Removing ideology is similar to "normative subtracting" (Sonenshein, 2006), which occurs when individuals make fewer normative arguments about an issue in public justifications than they do in private reasoning. However, while normative subtracting involves only rhetoric and language, removing ideology also involves material practices. In addition, removing ideology involves replacing ideological language and behavior with more neutral practices that emphasize choice and service, whereas normative subtracting involves a gap in the number of normative arguments in public relative to private discourse but not necessarily their replacement with alternative language.

In a lengthy discussion I observed during a store meeting, for example, a pluralist store manager explained that customer service was about "providing a service to our community” (M76). His reference to "our community" appealed to the many idealists at the store, who had resisted earlier efforts to improve customer service that had been framed in terms of sales. At the same time, because it did not explicitly incorporate ideological claims, the message was also well received by capitalists. At another store meeting, a pluralist store manager told employees to "keep the dogma out of the workplace," then detailed how to do this:

Say I'm very conservative about recycling and a customer at my register asks for separate bags for her items and wants them double bagged as well. You just do it for them, even if that would not be your personal choice. And you don't make any comments or give them a look that suggests you disapprove. Or say you're a vegan and someone asks you about a product you don't eat. You say, "Well, that's not my personal choice." Our job is not to judge what people want to buy. (M92)

Routinizing ideology. While they removed explicit discussion of ideological principles, pluralist managers simultaneously routinized those principles by implementing formal policies to carry out Natural Foods' social mission. Some policies affected daily work tasks and required employee involvement. For example, there were strict procedures for maintaining the "integrity" of organic products, regular audits to ensure compliance, and a formal system for customers to report possible violations of these practices. Whether or not members cared about promoting natural foods and healthy eating, these practices had to be followed. Employee involvement in other practices was voluntary. For example, Natural Foods sponsored community events such as food festivals or benefits for local non-profits, and employees were asked to help prepare for and staff these events. In addition, employees were eligible for a $20 \%$ discount on store purchases, a policy that encouraged people who had not previously tried natural or organic food to do so.

In part because they cared deeply about the underlying societal values, pluralist managers ensured required policies for implementing the social mission were followed, and they actively encouraged employees to become involved in voluntary programs. One store manager explained:

We do things to get people more involved. There's a breast cancer walk [next month], and we're also part of [a food and wine festival]. That's a fun thing to get people involved in because they can see our really good quality, delicious food and [see] people appreciating it. (M34) 
Pluralist managers also recognized and accepted that different types of involvement were appropriate for different individuals, and they customized their efforts accordingly. When a department manager learned of an employee's interest in recycling, for example, she directed him to the person in charge of establishing composting programs at each store. "I think he's talked with her a couple of times now," the manager explained, "and she's coming to the store to meet with him. I'm going to sit in with him" (M45).

\section{Identification Processes and Outcomes}

The practices described above influenced identification through three intervening processes. When pluralist managers developed integrative solutions, removed ideology, and routinized ideology, this validated the identities of idealists, capitalists, and pluralists through a process of "identity confirmation" in which members perceived the identity attributes they valued to be upheld. In addition, when pluralist managers routinized ideology, this altered the identities of capitalists and indifferent members through a process of "identity conversion" that led these members to place greater importance on Natural Foods' societal values. In contrast, the absence of these practices led some members to experience "identity violation" as they interpreted others' behavior as sacrilegious. I describe these processes below, showing how identity confirmation and conversion led to identification, while identity violation gave rise to dis-identification. Table 4 provides additional examples.

Identity confirmation. Identity confirmation occurred when members perceived the values they cherished to be upheld. It was fostered by all three identification management practices. First, integrative solutions confirmed and validated the values that idealists, capitalists, and pluralists held to be personally important, by directing members' attention to products and work practices that advanced both societal and economic values. Local products, for example, appealed to idealists' and pluralists' desire to support small-scale producers, who they perceived as more authentically organic and sustainable than large "industrial organic" producers. At the same time, local products resonated with capitalists' and pluralists' desire to generate profits and growth because they were popular with customers and tended to be more profitable. As a capitalist department manager noted, "a lot of people like to try local products” (M46).
Second, removing ideology helped capitalists and pluralists feel welcome within Natural Foods by conveying an open, inclusive vision of the social mission. It sent a message that one did not have to be in the purist natural foods club in order to positively contribute to the company. An incident described by a capitalist department manager illustrates this process. When one of his employees criticized him for not being knowledgable about natural foods:

My boss told him that if you take people like [me] out of this company, you're not going to have a company because you can't fill a company of this size with just foodies. It's not going to work. You need conventional people [like me] who don't eat everything on the shelves. (M40)

This type of behavior signaled to the manager in question that his own values and behaviors were appreciated and would be upheld, and it validated the contributions he made to Natural Foods.

Finally, when managers routinized ideology by enforcing formal procedures for enacting the social mission, this sent a powerful symbolic message to idealists and pluralists, who interpreted routinization as a signal that the values they cherished were being upheld. For example, an employee described with reassurance the company's organic integrity procedures: "In produce, they have an organic side and a non-organic. If you mix that stuff up together you are in hot water, so you really have to know what you are talking about and what you are doing" (E82). A department manager emphasized, "There are so many safeguards in place along the path that the food travels. I know most places do not take that much care" (M22).

Identity confirmation in turn enabled identification. This occurred as idealists, capitalists, and pluralists saw their values reflected in the organization, leading them to feel a sense of belonging and to value organizational membership. As an idealist employee explained:

I see that they're trying real hard to do something so great, and I believe in that. I reflect off of them and I reflect to them. It's all one big circle. It's like a big chain. I would love to stay here for as long as I can to build myself. This is actually helping me and my insides come out. (E07)

Similarly, for capitalists, perceptions that Natural Foods was upholding the economic values they held to be important led them to value being a part of the organization. Discussing Natural Foods' social and business missions, a department manager told me with pride, "We can talk about core values 
TABLE 4

Representative Data for Identification Processes and Outcomes

Conceptual Categories Empirical Themes and Representative Data

Identification Processes Identity Confirmation

Identity Conversion

Identity Violation

Identification Outcomes Identification

Dis-identification
Perceiving NF's societal and/or economic values to be upheld

CEO decides to ban the sale of live lobsters because the only available storage tanks do not allow for the crustaceans to be treated humanely. Idealist employee interprets this as evidence that leaders are "sticking to our values about the humane treatment of animals" (interview E04).

"In the stores that I've been in, the store managers go by the mission. They make sure that department managers do the same for their employees. It's like a domino effect. Regional is always making sure that the stores are going by it, and store leadership does the same to department managers, to employees. So it is what it is. We walk our talk" (interview M33).

Placing more importance on NF's values of health, community welfare, or environmental sustainability over time

"Because we are talking about [environmental sustainability] all the time and doing that at work. It becomes something important. You realize how important it is" (interview M73).

"Five-years ago. I was a Coke and Twinkies [guy]. It's just different. It changed. I mean, your diet changes" (interview M44).

Perceiving NF's values of health, community welfare, or environmental sustainability to be morally violated

"[An employee] would come to me and tell me how upset he was that he saw someone put cardboard in the trash. He would hide out above the trash compactors and see someone and report it to me" (interview M56).

"The products we carry do not meet the same standards they used to. [The company] started out as a place where they didn't have products with sugar in them. Now they sell chips from Frito Lay, for a while we had Huggies diapers, we have Heinz ketchup. I think you owe it to the public [to sell healthy food] if you are presenting yourself as Natural Foods and not processed foods. It's a deception that is hurting people's health. It's actually ruining people's health. It's huge. That's what [Natural Foods is] supposed to be all about, and I think that's the biggest lie" (interview E84).

Valuing being a part of $N F$

"I want to be here, and it's because I am passionate about it. I drive up here every day, I walk through these doors, and I feel good about what I'm doing. So I take a lot of pride in it" (interview E10).

"[Natural Foods] means a great deal to me. I sleep a lot better at night knowing that I'm working for good folks who are doing good things. It's one of the things that keeps me here without question. I'm always proud to say that I work for this company. Any time that [Natural Foods] is mentioned, people always associate [doing good] with this company. So it's a good association. I'm so happy to be a part of something like that" (interview M22).

Distancing oneself from NF and describing NF negatively, in opposition to one's own values

"Things like that [an incident with a store manager] get me really disillusioned. Our customers come in and think it's the most wonderful store and it's a great place to work and a great place to shop. But I keep thinking I need to find another job" (interview E41).

"I kind of withdrew. I go in, I do my job, and I do it the way I am supposed to do it. I do it well, I think, but I don’t feel the same way about the company. I don't feel like I represent Natural Foods or it represents me" (interview E84). and integrity and all that we want, but it's also a company who, bottom line, has made a lot of money and employs a lot of people" (M24). It was that fact that Natural Foods delivered on its commitment to being a successful business that enabled him to positively identify with the organization. "The most important thing that [Natural Foods] does is run a great company and employ a lot of people," he explained. "It has got to be the best company to work for in this industry." Pluralists also depicted instances in which their identities were confirmed as contributing to their identifica- tion. Talking about what it meant to work at Natural Foods, a pluralist employee described the company as "an oasis," providing "an environment where I feel 100\% accepted and supported" (E02). A pluralist store manager explained:

[Working at Natural Foods] is not just a job, it definitely is more than a job. It's one of the ways that I can make a difference in the world-not just by being a profitable store and helping the company make good decisions about what we spend money on, but also in day-to-day life where I am interacting with people and trying to help people grow and develop in 
ways that are meaningful to them. I think it kind of helps me to bring a lot of my own philosophy together. I can make a living, and I can also do something where I feel like I am making difference. (M76)

Identity conversion. Identity conversion involved a change in the identity of members who were initially capitalist or indifferent. It was prompted by the routinization of ideological values, which exposed members to the social mission and involved them in carrying it out, regardless of whether or not they had initially found this mission to be personally important. Indifferent members, for example, described in detail how they maintained organic integrity in the produce and meat departments by using separate sinks and cutting boards for organic and conventional produce, and by placing organic produce on the highest storage shelves so that it would not be contaminated by water dripping from conventional produce. Over time, such exposure and involvement led members to develop a greater appreciation of Natural Foods' societal values and to incorporate them into their own identity. One employee explained: "I've become, not a health food nut, but I've become more conscious of what I eat now" (E90).

Capitalists also described changes to their identity as a result of their involvement with the social mission. One employee, who was initially a capitalist but over time became a pluralist, explained: "I'm much more aware of what goes on around me since I've been working for this company. My core values have completely changed" (E18). A company-sponsored trip to a meat supplier, part of a program to help employees learn more about Natural Foods' products, was a critical turning point for him:

We went on a cattle drive. [We saw] the difference between naturally raised and conventional meats. We [saw] conventional cattle that were emaciated and didn't have any water or food. The difference was night and day. The cattle from [the company we visited] were really well taken care of. We went to the slaughterhouse, we saw the whole operation. I was amazed. The facility was more user-friendly for the cattle. They didn't have to suffer as much. (E18)

When members came to value aspects of Natural Foods' identity that they had not previously valued, being part of the organization became more important to them, fostering their identification. For example, an employee explained how working at Natural Foods had prompted her to reflect on the importance of health and humane treatment:
I came from the conventional way of doing things to the more healthy way. After I'd thought about their mission and read it, everything made sense to me. I wouldn't have thought about it if I didn't work here, about the compassion standards and foods without pesticides and all that. My husband and I have done a dietary change too, so it helps to be working for a place that makes it easier to stay away from processed foods, because we don't eat any of that stuff anymore. (E08)

As a result, she valued being part of the company: "It's nice to be able to be proud of what you sell and be able to stand behind it as being healthy and the animals aren't mistreated and there are not a lot of pesticides and things like that."

One might have expected identity conversion to occur among idealists as well, to the extent that they were exposed to and involved in Natural Foods' business operations. Idealists who were promoted to manager positions, for example, were given responsibility for economic outcomes, and this could have led them to better appreciate the importance of profits for maintaining the social mission (i.e., Lieberman, 1956). There was little support for this type of identity conversion in the data, however. Pluralist managers did not describe having previously been idealists, and the managers who were idealists did not show signs of starting to embrace economic values. In contrast, several idealist managers chose or were asked to step down from their management positions, and one left the company.

Identity violation. In the absence of pluralist managers' emphasis on integrative solutions, removing ideology, and routinizing ideology, some members experienced "identity violation," a process in which they interpreted others' behavior as morally violating the values they cherished. Identity violation is similar to "organizational sacrilege” (Harrison, Ashforth, \& Corley, 2009), defined as an action that "directly contradict[s] sacred ideals, values, beliefs and so on espoused by the organization" (page 225). Unlike organizational sacrilege, however, identity violation does not necessarily involve organizational acts. It can occur in response to the behavior of a specific individual, not just in response to the behavior of employees or management in general. Identity violation is also similar to perceived violation of a psychological contract (Morrison \& Robinson, 1997; see also Thompson \& Bunderson, 2003), but it involves expectations about who we are and what we do as an organization, which may or may not include expec- 
tations about the psychological contract, defined as reciprocal obligations between members and the organization (Rousseau, 1989).

Identity violation was often prompted by capitalist managers' tendency to emphasize one-sided rather than integrative solutions. For example, an idealist department manager described her frustration at the product promotion choices made by other managers. These individuals had prominently displayed "unhealthy" products near cash registers and had been supported in their actions by store managers "looking to promote sales." From her perspective, this behavior violated the company's commitment to promoting natural and organic foods. When she raised the issue at a manager meeting, however:

I could feel that everybody was uncomfortable with what I was saying. They really didn't want to hear it. Don't ever talk bad about the wine and the cheese and the fancy crackers, don't ever do that. Anywhere that the wine buyer wants to put stacks of wine, she's got it. She can put them on top of the register if she wants to. [Store managers] will let that happen, because they know that will make money. There are ethics involved there that I don't agree with. (M77)

Identity violation also arose when ideological principles were not routinized or when routinization was not enforced, as occurred under some capitalist managers. In the absence of routinization, members for whom Natural Foods' societal values were not important did little to enact them in their daily work, an omission that idealists interpreted as sacrilegious. For example, an idealist employee working in a store run by a capitalist manager expressed disappointment that the environmental mission was not being implemented:

My understanding is that it used to be higher on the list of priorities, that it's gone down [as Natural Foods became] part of the stock market and more interested in profit. Profit, profit, profit, profit. [Employees are] just throwing out their bottles of water in the trash. It's not emphasized to employees that [sustainability] is what we're trying to do and if we're doing it, then the customer will notice and maybe make more of an effort too. Every morning when I come in, there are plastic bottles thrown out from the night before. (E52)

As these examples illustrate, some identity violations involved instances in which employees perceived cherished values to be sacrificed in favor of other organizational values, as in the case of man- agers promoting profitable products instead of healthy products. Other identity violations involved instances in which cherished values were simply not enacted, as in the case of employees throwing away rather than recycling plastic bottles. What all these incidents had in common was the perception that others' behavior violated sacred values.

Notably, identity violation occurred only among idealists. When capitalists and pluralists perceived other members to behave in ways that were inconsistent with their own values-either by failing to enact those values or by trading them off for competing values-they accepted these differences rather than interpreting them as moral violations. Capitalists sometimes perceived profitability to be compromised in favor of the social mission, for example, but offered positive interpretations, concluding that Natural Foods was a company with integrity. As a store manager explained, "It's kind of neat to work for a company that will lose some sales for what they believe in. That's not normal. Or if items are being carried by a mass merchandiser, to cut them out of here. Is that a great short-term business decision? No. But is it going by what they believe in? Yeah" (M44). Similarly, when pluralists perceived societal values to be compromised in favor of profits, they tended to accept these instances. Talking about the introduction of more profitable but arguably less healthy products, a pluralist department manager explained, "Do I think we should be selling them? We still have to make money, you know" (M16). While this person perceived the new products to be inconsistent with the spirit of the social mission, he accepted regional managers' decision to sell them, in large part because he recognized, and valued, the economic benefits they would bring to the company.

Identity violation led to dis-identification, as members became disillusioned and distanced themselves from the organization. This process is well illustrated by the experience of a department manager (M79) in a store that had initially emphasized the social mission but had come under increasing pressure from regional management to focus on profits and growth. As part of this new focus, a group of regional managers were streamlining the number of products offered and standardizing product mix across all stores in the region. The department manager acknowledged the eliminated products were low in sales volume, but also perceived them to be more natural and healthy than the remaining products, and he 
found this privileging of financial over social concerns problematic. "Obviously it's going to change my approach to the job. I am not going to continue to fight for products, because they don't want to hear it." He also expressed frustration that many of his co-workers did not shop at Natural Foods. How could the store be genuinely committed to promoting health and sustainability, he asked, if it was not even convincing its own employees to shop there? When I returned to this site several months after conducting interviews, he told me he had given his two weeks' notice and accepted a job at a natural foods cooperative, explaining that continual compromising of the social mission in the name of profits had simply become unacceptable to him.

\section{A MODEL OF IDENTIFICATION WHEN MEMBERS HOLD DIVERGENT VALUES}

Taken together, the findings described above suggest a model of how identification develops when individuals hold divergent values. As shown in Figure 2, values are enacted through work behaviors, resulting in divergent and sometimes conflicting behaviors among organizational members. In such a context, the presence of pluralist managers and their enactment of three organizational practices contribute to the emergence of identification, whereas the absence of these practices allows disidentification to emerge.

The presence of pluralists in management positions is critical, as the nature of their personal identity combined with their managerial authority enables them not only to accept an organization's divergent values but also to foster such acceptance among others. As they recognize and embrace conflicting values, pluralists have "paradoxical cognition"- - they adopt mental frames and processes that enable them to simultaneously enact contradictory goals and values (Smith \& Tushman, 2005). They also engage in integratively complex thinking (Tetlock, 1986), recognizing the distinct value of multiple perspectives on an issue while integrating these multiple perspectives into a coherent whole. These characteristics insulate pluralists as individuals from experiencing identity violation and becoming dis-identified. They also help pluralists foster identification among other members. As pluralists value multiple organizational identity attributes and perceive these as mutually reinforcing and not conflicting, they have a "complementary identity structure" that enables them to build highquality relationships with diverse groups of people (Dutton et al., 2010). At Natural Foods, for example, pluralists were respected by both idealists and capitalists, and they helped members of each type to understand and appreciate one another's contribu-

FIGURE 2

A Process Model of Identification Based on Divergent Values

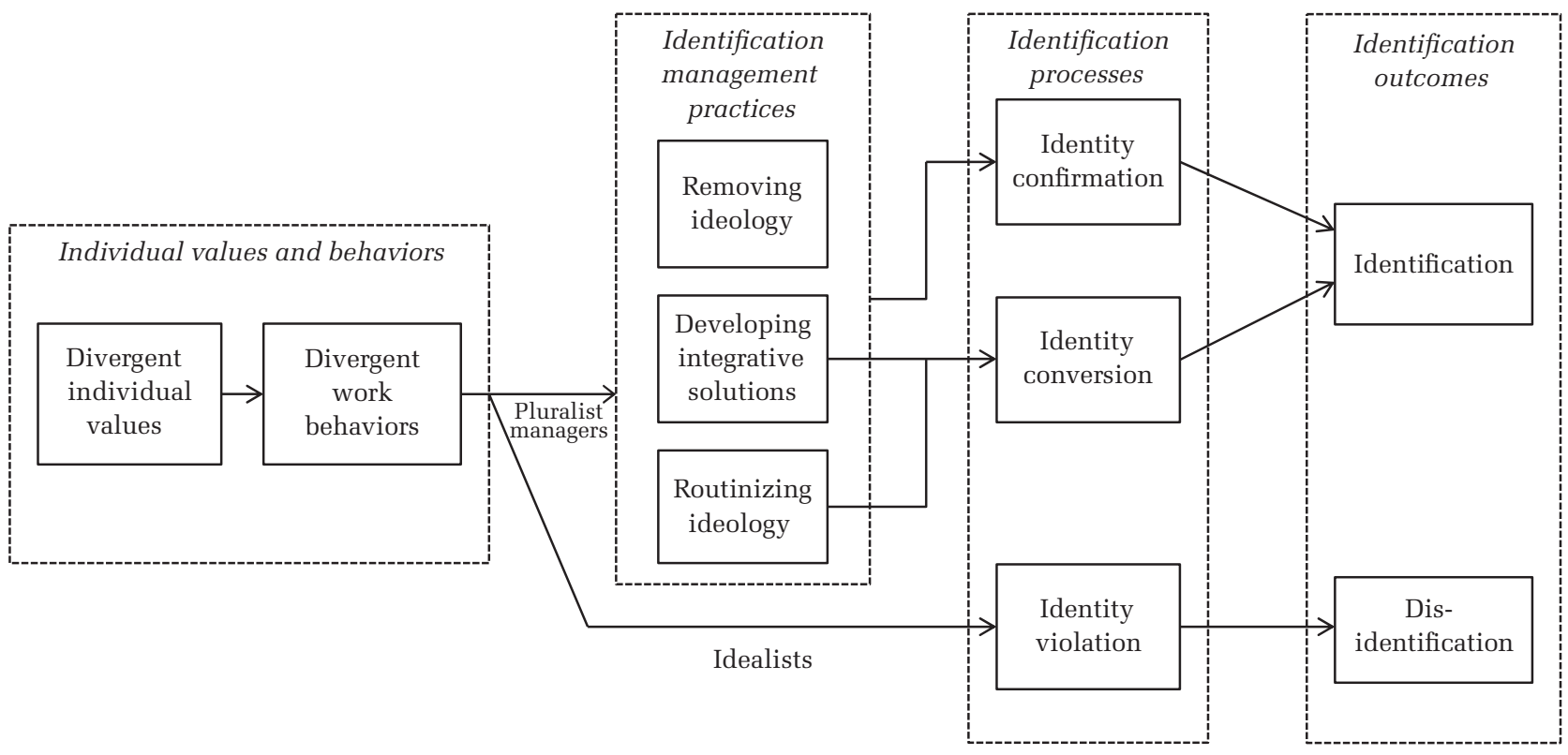


tions, mitigating dis-identification and promoting identification among individuals holding divergent values.

Pluralists foster identification by interpreting and enacting the organization's ideology in ways that confirm and expand members' identities. As shown in the middle of Figure 2, this involves three specific identification management practices. First, integrative solutions enable both sides of conflicting demands to be upheld (Suedfeld, Tetlock, \& Streufert, 1992). As they embody multiple sets of values simultaneously, integrative solutions allow idealists and capitalists to see that there is not necessarily a zero-sum competition between their values and the values of the other group. Members observe the values they cherish being enacted, and their identity is thereby confirmed. Integrative solutions could also foster identity conversion, although I did not find evidence of this at Natural Foods. As members recognize that other values support rather than conflict with their own, they may develop greater appreciation for those values, incorporating them into their personal identity.

Second, removing ideology enables identity confirmation. Ideological principles are seen as inviolable by those who cherish them (Harrison et al., 2009). This can create an environment in which non-believers are unwelcome. At Natural Foods, for example, the prohibition on adding white flour and sugar to baked goods alienated employees with a conventional grocery background. Likewise, giving dirty looks to customers who bought meat or who asked for plastic rather than paper bags may have alienated co-workers as well as customers. By removing ideology, pluralist managers created an open and inclusive environment, one that confirmed the identities of members for whom these ideological principles were not of high importance.

Finally, routinizing ideology fosters both identity confirmation and identity conversion. Routinization protects ideological principles by enshrining them in an organization's operational procedures. As Selznick recognized, values depend on "mundane administrative arrangements" in order to be sustained (Selznick, 1957). At Natural Foods, routines for maintaining organic integrity, as well as the creation of environmental teams, quality standards, and "local forager" positions (formal roles with responsibility for increasing the number of local products in each store) all served to maintain values of health, environmental sustainability, and community welfare. Absent such procedures, values become precarious and the identification of members for whom they are important is at risk. Routinization preserves the sacred, by making enactment of sacred values part of the organization's standard operating procedures. This fosters identity confirmation among members for whom these values are important, as they perceive their cherished values to be upheld and confirmed by the organization. At the same time, routinization neutralizes the ideological component of sacred values. Enacting these values is no longer an expression of individual ideology; it is simply a required work task. Because it makes enactment of ideological principles part of standard work routines, thereby involving members for whom these principles are not initially important in the act of carrying them out, routinization fosters identity conversion. Similarly, Fiol (2002) argues that engaging employees in new roles and projects that are specific and concrete can shift their self-conceptions.

In turn, identity confirmation and identity conversion lead to identification (see the upper right hand side of Figure 2). These relationships can be understood in terms of two identity comparisons that have been shown to be involved in identification. In one identity comparison, members implicitly or explicitly compare their own identity with the organization's identity (Ashforth \& Mael, 1989; Dutton et al., 1994). Identity conversion leads members to value identity attributes that were not previously important to them, thereby increasing the overlap of self-identity with organizational identity. This overlap meets members' need for self-continuity by enabling them to experience consistency between themselves and their enacted role within the organization (see Brickson, 2013). As a result, they value membership in the organization, experiencing identification. The relationship between identity confirmation and identification can be understood in terms of the second comparison, in which members' compare their expectations for the organization's identity with their perceptions of its actual identity (e.g., Foreman \& Whetten, 2002; Reger, Gustafson, Demarie, \& Mullane, 1994). When members see the values they cherish being confirmed-that is, when their expectations for the organization are confirmed by their perceptions of its actual behavior-this helps to fulfill their need for esteem, enabling them to feel worthy and "good" because expectations about identity attributes that are important to them have been met (see Brickson, 2013). As a result, they value membership in the organization, experiencing identification. 
In the absence of pluralist managers, divergent values and work behaviors lead members to experience identity violation, which in turn leads to dis-identification (see the bottom portion of Figure 2). At Natural Foods, identity violation occurred only among members for whom societal values alone were of high importance (i.e., idealists). Societal values have the potential to engender identity violation because they are terminal as opposed to instrumental values (see Rokeach, 1973) and, unlike economic values, they are also ideological rather than technical in nature. They represent virtues and ideals seen as morally correct, and are therefore held to be sacred (Harrison et al., 2009; Selznick, 1994). Attempts to translate sacred values into a common utility metric and trade them off against non-sacred objectives are likely to be interpreted as morally wrong, or "taboo," and people respond to these taboo trade-offs by expressing moral outrage (Douglas, 1966; Tetlock, Kristel, Elson, Green, \& Lerner, 2000). As pluralists also placed high importance on societal values, one might have expected them to experience identity violations as well. However, when individuals hold competing values to be equally important, they engage in integratively complex thinking (Tetlock, 1986), which may enable them to accept instances in which societal values are traded off for economic values.

The experience of identity violation in turn leads to dis-identification. In the present study, members who experienced identity violation came to define themselves in opposition to the organization, even as they continued to support the social mission Natural Foods espoused. They became disillusioned, reduce their work effort, and, in some cases, left the organization. Similarly, Cha and Edmondson (2006) show how employees of an advertising agency became disillusioned with the company when they perceived the CEO to violate the values they held dear. Gutierrez et al. (2010) show how members of the Catholic Church dis-identified with the Church as an organization following sexual abuse scandals, although they continued to support the normative values that it espoused.

\section{DISCUSSION}

This research builds theory about how identification emerges when members differ in which organizational values they hold to be important. It is relatively well established that conflict and disidentification develop under such conditions. In contrast, the process model developed in this paper shows how identification as well as dis-identification arise amid divergent values. The model unpacks how pluralist managers' practices of developing integrative solutions and simultaneously removing and routinizing ideology foster identification, and it shows how the absence of these practices creates conditions under which member interactions lead to dis-identification. In doing so, the model advances understanding of the relational dynamics of identification, offers new insight into how organizations can benefit from multiple identities, and illuminates the double-edged sword of ideology in organizations.

\section{The Relational Dynamics of Organizational Identification}

This study contributes to theories of organizational identification by offering insight into the relational and interactive processes that underpin identification. While identification as a state is defined in terms of the relationship an individual has with their organization (Ashforth \& Mael, 1989; Ashforth et al., 2008; Dutton et al., 1994; Elsbach, 1999), processes of identity formation and identification are fundamentally relational-they involve interactions with and cues from others both within and beyond the boundaries of the organization (Gioia et al., 2000). Consistent with social information processing theory (Salancik \& Pfeffer, 1978), extant research shows that cues from others can affirm (or disaffirm) members' understanding of their organization's identity (Dutton \& Dukerich, 1991) and their self-identity (Wrzesniewski, Dutton, \& Debebe, 2003), and this can in turn influence identification. In addition, identification with other organizational members can lead individuals to identify with the organization as a whole (Sluss \& Ashforth, 2008). Nevertheless, this research has largely neglected to consider what happens when members differ in their values and behavior, and therefore provide potentially conflicting cues to individuals about organizational and self-identity. Meanwhile, research that does emphasize value differences suggests they lead to conflict and disidentification but does not explain the emergence of identification (e.g., Glynn, 2000).

The present study builds on and extends this work by contributing an empirically grounded model that explains how interactions among members who hold divergent values can lead to both identification and dis-identification. The model in- 
dicates that in the presence of conflicting values and behaviors, whether interactions among members lead to identification or dis-identification depends on how managers interpret and enact organizational identity for frontline employees. When managers develop integrative solutions, remove ideology, and routinize ideology, this enables identification to emerge despite the presence of conflicting values and behaviors among co-workers. In contrast, when managers do not engage in these practices, interactions among co-workers with conflicting values give rise to dis-identification.

Interactions among members may be particularly important to identification processes in organizations whose identities include divergent values, and whose members differ in the importance they place on these values. In such settings, differences across members create the potential for dis-identification, not just identification. However, interactions among members are likely to be critical to identification even in organizations that do not have divergent values, because it is through interacting with others that individuals perceive the organizational values they cherish to be confirmed, and incorporate additional organizational values into their self-identities. These processes of identity confirmation and identity conversion are, in turn, what enable identification.

In showing how identification can arise from interactions among members who hold divergent values, this study makes a second contribution to theories of identification: it connects top-down approaches to managing identity and identification (e.g., Clark et al., 2010; Gioia, Price, Hamilton, \& Thomas, 2010; Pratt \& Corley, 2007; Pratt \& Foreman, 2000) with bottom-up processes among frontline employees (e.g., Golden-Biddle \& Rao, 1997; Gutierrez et al., 2010; Pratt \& Rafaeli, 1997). Prior research tends to focus on one or the other of these approaches. The present study brings these steams of work together, showing how identification arises from the combination of particular relational dynamics among members with particular management practices. An important implication is that to fully understand identification, researchers must consider top-down and bottom-up processes jointly, rather than in isolation.

Finally, by connecting top-down and bottom-up approaches to identification, this study offers a new way of understanding the management of identification. Whereas extant research focuses on managing identification by altering the nature of the relationship individuals have with their organiza- tions (e.g., Pratt, 2000), the model that emerged from the present study suggests organizations can also manage identification by influencing the nature of members' interactions with one another. Practices of developing integrative solutions, removing ideology, and routinizing ideology enable interactions among members to foster identification rather than dis-identification. In this way, the present study shifts the focus of extant theorizing about how to manage identification, from organizational practices that influence individual members directly to those that facilitate interactions among members.

\section{How Organizations Can Benefit from Multiple Identities}

This study also contributes to our understanding of multiple identities in organizations. Existing research tends to treat multiple identities as problematic. Studies emphasize the potential for conflict and mutual dis-identification to emerge among members, leading to declining organizational performance (Anteby \& Wrzesniewski, 2014; Glynn, 2000; Golden-Biddle \& Rao, 1997; Pratt \& Rafaeli, 1997; Voss et al., 2006). Research in other domains of organizational theory similarly depicts multiple identities, values, and other dualities-defined as simultaneous and seemingly contradictory elements (Ashforth \& Reingen, in press)—as sources of tension and conflict. At the group level, value diversity within workgroups is associated with lower cohesion (Harrison, Price, \& Bell, 1998; Harrison, Price, Gavin, \& Florey, 2002) and increased conflict (Jehn, Chadwick, \& Thatcher, 1997; Jehn, Northcraft, \& Neale, 1999). At the organizational level, research on ambidexterity highlights the challenges that arise when organizations attempt to explore new capabilities while simultaneously exploiting existing ones (Andriopoulos \& Lewis, 2009; Smith \& Tushman, 2005). Research on organizational paradox emphasizes the tendency for contradictory yet interrelated elements to lead to defensive reactions and vicious cycles in organizations (Smith \& Lewis, 2011). At the societal level, institutional research suggests uncertainty and contestation arise when organizations confront multiple logics that offer incompatible prescriptions for action (Besharov \& Smith, 2014; Greenwood, Raynard, Kodeih, Micelotta, \& Lounsbury, 2011; Kraatz \& Block, 2008).

The present study enriches our understanding of multiple identities and other dualities within organizations by showing how they not only create challenges, but also can offer benefits for organiza- 
tions. It further illuminates the central role pluralist managers play in enabling organizations to attain these benefits. Pluralists are valuable not only because they accept trade-offs between conflicting values, which enables them as individuals to maintain identification, but also because of their influence on other members. Pluralists foster identification among others by combining practices that integrate divergent values with those that differentiate and uphold the distinct contributions of each type of value. At Natural Foods, pluralists integrated divergent values by developing work practices and promoting products that simultaneously embodied societal and economic values. They upheld each type of value as distinct by recognizing and acknowledging the contributions made by capitalists and idealists, and by simultaneously removing and routinizing ideology. Removing ideology upheld Natural Foods' economic values, eliminating one-sided behavior in which societal values were enacted at the expense of economic. Routinizing ideology upheld Natural Foods' societal values, ensuring they were enacted in required work practices. Although they operate at a different level of analysis, these practices are similar to organization-level strategies for managing multiple identities discussed in prior research, which also involve integrating and differentiating (e.g., Pratt \& Foreman, 2000).

By illuminating the role that frontline managers play in enabling organizations to benefit from multiple identities, the present study complements and extends ideas that have been put forth in other domains of organizational theory. Benefiting from multiplicity and pluralism is not just a matter of institutional position (Seo \& Creed, 2002), organizational design (Battilana \& Lee, 2014; Pache \& Santos, 2013), or senior leadership (Smith, in press; Smith \& Tushman, 2005), nor does it require that all members hold all organizational values (Gibson \& Birkinshaw, 2004). Organizations can also benefit from multiplicity through the on-the-ground practices of frontline managers who hold conflicting values and who bridge potential faultlines between them. This insight implies that to fully understand multiple identities and other dualities in organizations, we need to examine internal dynamics and practices among members (e.g., Smets, Jarzabkowski, Burke, \& Spee, 2014), not just factors operating at the level of the institutional environment, the organization, or the senior team.

\section{The Double-Edged Sword of Ideology in Organizations}

This study also offers insight into the role of ideology in organizations. Some research suggests organizations that appeal to ideology benefit from providing a context in which members can realize deeply held values. Doing so enhances motivation (Shamir, 1990), cooperation (Barnard, 1938), and commitment (Kanter, 1972; O'Reilly \& Chatman, 1986). In addition, organizations that embody ideological values can make significant contributions to society as a whole, leading some scholars to advance normative arguments for incorporating such values into organizations and organizational theory (Selznick, 1994; Margolis \& Walsh, 2003). However, other research indicates a dark side to ideology, showing how disillusionment and disidentification can arise when members perceive violations of ideological values (Ashforth \& Reingen, in press; Thompson \& Bunderson, 2003).

The present study brings together these disparate streams of research, explicating how the downsides of ideology evident in the latter studies can be overcome to achieve the organizational and societal benefits of incorporating ideological values. It further indicates that these benefits are achieved in part by removing explicit discussion and promotion of ideological values from day-to-day work. This finding may at first appear counterintuitive, particularly given that organizations with strong and relatively unique identities, such as those based on ideological values, tend to trumpet those identities in order to keep them vibrant (Elsbach \& Kramer, 1996; Gioia et al., 2010). When coupled with routinization, however, removing ideology from day-to-day work enables organizations to appeal to a wider range of members-routinization of ideology reassures idealists that the values they cherish are being upheld, while removing ideology allows other members to feel welcome within the organization.

\section{Limitations and Future Directions}

As with any qualitative research that develops theory from a single case, this study has limitations, several of which suggest directions for future research. One fruitful area for further investigation concerns the role that direct contact among members who hold divergent values plays in identification and dis-identification. At Natural Foods, idealists, capitalists, pluralists, and indifferent 
members encountered one another frequently in their daily work, providing opportunities for them to see first hand the differences in their behaviors. However, one of the stores in the present study had previously been isolated from other stores due to its remote location. Most staff members at that location were idealists, they were not in frequent, direct contact with non-idealists, and they reported experiencing few instances of identity violation during that time. This offers suggestive evidence that direct contact among members creates greater potential for dis-identification, and increases the need for pluralists and the identity management practices they enact. However, the retrospective interview data on which this conclusion is based make it tentative at best, calling for further research on the extent to which the relational ecology of identification depicted in this study depends on direct contact with others. Addressing this issue will require ethnographic and longitudinal studies that investigate how interactions among members unfold over time.

A second area for future research concerns how organizations attain pluralist members. Understanding this issue is particularly important, given the central role these individuals play in the identification process. At Natural Foods, pluralists appeared to be favored for promotion to department and store manager positions, suggesting selection plays at least some role. The data also indicated capitalist members could be socialized to incorporate ideological values into their identities through exposure to, and involvement in, the social mission, thereby becoming pluralists. Yet, there was no evidence of socialization leading idealists to incorporate economic values, although prior research suggests this could occur when idealists become managers and are given responsibility for economic outcomes (e.g., Lieberman, 1956). Taken together, these findings suggest the presence of pluralists is likely to be influenced by both socialization and attraction-selection-attrition processes (e.g., Chatman, 1991; Schneider, 1987; Sidanius, Pratto, Van Laar, \& Levin, 2004). However, the qualitative and cross-sectional nature of the data precludes drawing firm conclusions about the relative importance of these processes. Future studies with larger sample sizes and longitudinal designs are needed to develop a more robust understanding of how pluralists emerge, and specifically to investigate how and to what extent this process involves socialization versus attraction, selection, and attrition.

\section{Practical Implications}

Organizations with divergent values face critical questions about who to hire-people who endorse multiple values, those who adhere to just one type of value, or "blank slates" not tied to any organizational values-and how to socialize and promote these individuals. Prior research suggests organizations can overcome conflict and dis-identification by hiring "blank slates" and socializing them to identify with a neutral organizational identity rather than one based on divergent values (Battilana \& Dorado, 2010). However, the "blank slate" approach may not be feasible for many organizations, particularly older and larger ones whose employees are already committed to particular values. The present study suggests an alternative: organizations can hire people who adhere to just one type of value or the other, provided they also develop managers who support both types of values. The presence of these pluralist managers, and the practices in which they engage, enables organizations to foster identification among employees despite differences in their values.

Given the central role that pluralist managers play, it is tempting to conclude that organizations with divergent values should hire and promote only pluralists. However, something may be lost when organizations lack distinct representation of the values they embody. In group decision making, for example, the absence of formal practices, roles, or structures that represent alternative perspectives can lead a single, initial point of view to dominate (Nemeth, 1986; Schweiger, Sandberg, \& Ragan, 1986). Similarly, when firms lack distinct representatives of an innovative new technology, their efforts to pursue innovation are likely to fail, as the existing technology remains dominant (Tripsas \& Gavetti, 2000). In the same way, when organizations embody divergent values, the absence of distinct representatives of each value may lead a single value to prevail. To the extent that organizations want or need to uphold divergent values, hiring people who represent all those values together, but also people who represent each individual value, may therefore be the most effective approach.

\section{CONCLUSION}

As organizations operate in global markets, incorporate diverse employee populations, combine exploitation of existing products with exploration of new products, and pursue social goals alongside 
financial success, they will increasingly develop identities that combine divergent values. This study proposes a model of how identification develops in such a context. It unpacks the relational ecology of identification, showing how identification can arise from interactions among members who hold divergent values. It further highlights the central role played by pluralist members, who embrace not just single values within an organization's identity but all those values together. By integrating divergent values while also maintaining their distinctions, pluralists enable members who might otherwise succumb to dis-identification to achieve identification. In this way, the study provides a critical foundation for further exploration of how organizations can attain the benefits of identification even as their identities include divergent values.

\section{REFERENCES}

Albert, S., Ashforth, B. E., \& Dutton, J. E. 2000. Organizational identity and identification: Charting new waters and building new bridges. Academy of Management Review, 25: 13-17.

Albert, S., \& Whetten, D. A. 1985. Organizational identity. In L. L. Cummings \& B. M. Staw (Eds.), Research in organizational behavior, vol. 7: 263-295. Greenwich, CT: JAI Press.

Andriopoulos, C., \& Lewis, M. W. 2009. Exploitationexploration tensions and organizational ambidexterity: Managing paradoxes of innovation. Organization Science, 20: 696-717.

Anteby, M., \& Wrzesniewski, A. 2014. In search of the self at work: Young adults' experiences of a dual identity organization. Research in the Sociology of Work, 25: 13-50.

Ashforth, B. E., \& Reingen, P. H., in press. Functions of dysfunction: Managing the dynamics of an organizational duality in a natural food cooperative. Administrative Science Quarterly.

Ashforth, B. E., Harrison, S. H., \& Corley, K. G. 2008. Identification in organizations: An examination of four fundamental questions. Journal of Management, 34: 325-374.

Ashforth, B. E., \& Mael, F. 1989. Social identity theory and the organization. Academy of Management Review, 14: 20-3910.5465/AMR.1989.4278999].

Barnard, C. 1938. The functions of the executive. Cambridge: Harvard University Press.

Bartel, C. A. 2001. Social comparisons in boundary-spanning work: Effects of community outreach on mem- bers' organizational identity and identification. $\boldsymbol{A d}$ ministrative Science Quarterly, 46: 379-414.

Battilana, J., \& Dorado, S. 2010. Building sustainable hybrid organizations: The case of commercial microfinance organizations. Academy of Management Journal, 53: 1419-1440.

Battilana, J., \& Lee, M. 2014. Advancing research on hybrid organizing: Insights from the study of social enterprises. Academy of Management Annals, 8: 397-441.

Benet-Martinez, V., Leu, J., Lee, F., \& Morris, M. W. 2002. Negotiating biculturalism: Cultural frame switching in biculturals with oppositional versus compatible cultural identities. Journal of Cross-Cultural Psychology, 33: 492-516.

Besharov, M. L., \& Smith, W. K. 2014. Multiple institutional logics in organizations: Explaining their varied nature and implications. Academy of Management Review, 39: 364-381.

Brickson, S. L. 2013. Athletes, best friends, and social activists: An integrative model accounting for the role of identity in organizational identification. Organization Science 24: 226-245.

Cha, S. E., \& Edmondson, A. C. 2006. When values backfire: Leadership, attribution, and disenchantment in a values-driven organization. Leadership Quarterly, 17: 57-78.

Chatman, J. A. 1991. Matching people and organizations: Selection and socialization in public accounting firms. Administrative Science Quarterly, 36: 459484.

Clark, S. M., Gioia, D. A., Ketchen, D. J., \& Thomas, J. B. 2010. Transitional identity as a facilitator of organizational identity change during a merger. Administrative Science Quarterly, 55: 397-438.

Douglas, M. 1966. Purity and danger. London: Routledge.

Dukerich, J. M., Golden, B. R., \& Shortell, S. M. 2002. Beauty is in the eye of the beholder: The impact of organizational identification, identity, and image on the cooperative behaviors of physicians. Administrative Science Quarterly, 47: 507-533.

Dutton, J. E., \& Dukerich, J. M. 1991. Keeping an eye on the mirror: Image and identity in organizational adaptation. Academy of Management Journal, 34: 517-554.

Dutton, J. E., Dukerich, J. M., \& Harquail, C. V. 1994. Organizational images and member identification. Administrative Science Quarterly, 39: 239-263.

Dutton, J. E., Roberts, L. M., \& Bednar, J. 2010. Pathways for positive identity construction at work: Four types of positive identity and the building of social re- 
sources. Academy of Management Review, 35: 265-293.

Edmondson, A. C., \& McManus, S. E. 2007. Methodological fit in management field research. Academy of Management Review, 32: 1155-1179.

Eisenhardt, K. M. 1989. Building theories from case study research. Academy of Management Review, 14: 532-550 [CrossRef:10.5465/AMR.1989.4308385].

Elsbach, K. 1999. An expanded model of organizational identification. In R. I. Sutton \& B. M. Staw (Eds.), Research in organizational behavior, vol. 21: 163200. Greenwich, CT: JAI Press.

Elsbach, K. 2001. Coping with hybrid organizational identities: Evidence from california legislative staff. In J. Wagner (Ed.), Advances in qualitative organizational research, vol. 3: 59-90. Oxford, U.K.: Elsevier Science Ltd.

Elsbach, K. D., \& Cable, D. M. 2012. Identifying with NASCAR: Prestige, value congruence, and collective identification (Working Paper ed.). Davis, CA: University of California, Davis.

Elsbach, K. D., \& Kramer, R. M. 1996. Members' responses to organizational identity threats: Encountering and countering the business week rankings. Administrative Science Quarterly, 41: 442.

Fauchart, E., \& Gruber, M. 2011. Darwinians, communitarians, and missionaries: The role of founder identity in entrepreneurship. Academy of Management Journal, 54: 935-957.

Fiol, C. M. 2002. Capitalizing on paradox: The role of language in transforming organizational identities. Organization Science, 13: 653-666.

Fiol, C. M., Pratt, M. G., \& O’Connor, E. J. 2009. Managing intractable identity conflicts. Academy of Management Review, 34: 32-55.

Foreman, P., \& Whetten, D. A. 2002. Members' identification with multiple-identity organizations. Organization Science, 13: 618-635.

Gibson, C. B., \& Birkinshaw, J. 2004. The antecedents, consequences, and mediating role of organizational ambidexterity. Academy of Management Journal, 47: 209-226.

Gioia, D. A. 1998. From individual to organizational identity. In D. A. Whetten \& P. C. Godfrey (Eds.), Identity in organizations: Building theory through conversations: $17-31$. Thousand Oaks, CA: Sage.

Gioia, D. A., Price, K. N., Hamilton, A. L., \& Thomas, J. B. 2010. Forging an identity: An insider-outsider study of processes involved in the formation of organizational identity. Administrative Science Quarterly, 55: $1-46$.

Gioia, D. A., Schultz, M., \& Corley, K. G. 2000. Organi- zational identity, image, and adaptive instability. Academy of Management Review, 25: 63-81 [CrossRef:10.2307/259263].

Glaser, B. 2002. Conceptualization: On theory and theorizing using grounded theory. International Journal of Qualitative Methods, 1: 23-38.

Glaser, B., \& Strauss, A. 1967. The discovery of grounded theory: Strategies for qualitative research. New York: Aldine de Gruyter.

Glynn, M. A. 2000. When cymbals become symbols: Conflict over organizational identity within a symphony orchestra. Organization Science, 11: 285-298.

Golden-Biddle, K., \& Rao, H. 1997. Breaches in the boardroom: Organizational identity and conflicts of commitment in a nonprofit organization. Organization Science, 8: 593-611.

Greenwood, R., Raynard, M., Kodeih, F., Micelotta, E. R., \& Lounsbury, M. 2011. Institutional complexity and organizational responses. Academy of Management Annals, 5: 317-371.

Gutierrez, B., Howard-Grenville, J., \& Scully, M. A. 2010. The faithful rise up: Split identification and an unlikely change effort. Academy of Management Journal, 53: 673-699.

Harrison, D. A., Price, K. H., \& Bell, M. P. 1998. Beyond relational demography: Time and the effects of surface- and deep-level diversity on work group cohesion. Academy of Management Journal, 41: 96107.

Harrison, D. A., Price, K. H., Gavin, J. H., \& Florey, A. T. 2002. Time, teams, and task performance: Changing effects of surface- and deep-level diversity on group functioning. Academy of Management Journal, 45: 1029-1045.

Harrison, S. H., Ashforth, B. E., \& Corley, K. G. 2009. Organizational sacralization and sacrilege. In A. P. Brief \& B. M. Staw (Eds.), Research in organizational behavior, vol. 29: 225-254. Oxford, U.K.: Elsevier.

Hochschild, A. R. 1983. The managed heart: Commercialization of human feeling. Berkeley, CA: University of California Press.

Hoffman, A. J., Badiane, K. K., \& Haigh, N. 2012. Hybrid organizations as agents of positive social change: Bridging the for-profit and non-profit divide. In K. Golden-Biddle \& J. Dutton (Eds.), Exploring Positive Social Change in Organizations: 131-153. New York: Routledge, Taylor \& Francis Group.

Jehn, K. A., Chadwick, C., \& Thatcher, S. M. B. 1997. To agree or not to agree: The effects of value congruence, individual demographic dissimilarity, and conflict on workgroup outcomes. International Journal of Conflict Management, 8: 287-305. 
Jehn, K. A., Northcraft, G. B., \& Neale, M. A. 1999. Why differences make a difference: A field study of diversity, conflict, and performance in workgroups. Administrative Science Quarterly, 44: 741-763.

Kanter, R. M. 1972. Commitment and community: Communes and utopias in sociological perspective. Cambridge, MA: Harvard University Press.

King, B. G., Felin, T., \& Whetten, D. A. 2010. Perspective-Finding the organization in organizational theory: A meta-theory of the organization as a social actor. Organization Science, 21: 290-305.

Kraatz, M., \& Block, E. 2008. Organizational implications of institutional pluralism. In R. Greenwood, C. Oliver, R. Suddaby \& K. Sahlin-Andersson (Eds.), Handbook of organizational institutionalism: 243275. London: Sage Publications.

Kreiner, G. E., \& Ashforth, B. E. 2004. Evidence toward an expanded model of organizational identification. Journal of Organizational Behavior, 25: 1-27.

Lieberman, S. 1956. The effects of changes in roles on the attitudes of role occupants. Human Relations, 9: 385-402.

Mael, F. A., \& Ashforth, B. E. 1995. Loyal from day one: Biodata, organizational identification, and turnover among newcomers. Personnel Psychology, 48: 309333.

Mael, F., \& Ashforth, B. E. 1992. Alumni and their alma mater: A partial test of the reformulated model of organizational identification. Journal of Organizational Behavior, 13: 103-123.

Margolis, J. D., \& Walsh, J. P. 2003. Misery loves companies: Rethinking social initiatives by business. Administrative Science Quarterly, 48: 268-305.

Miles, M. B., \& Huberman, A. M. 1994. Qualitative data analysis: An expanded source book. Thousand Oaks: SAGE Publications.

Morrison, E. W. 1994. Role definitions and organizational citizenship behavior: The importance of the employee's perspective. Academy of Management Journal, 37: 1543-1567.

Morrison, E. W., \& Robinson, S. L. 1997. When employees feel betrayed: A model of how psychological contract violation develops. Academy of Management Review, 22: 226-256 [CrossRef:10.2307/ 259230].

Nag, R., Corley, K. G., \& Gioia, D. A. 2007. The intersection of organizational identity, knowledge, and practice: Attempting strategic change via knowledge grafting. Academy of Management Journal, 50: 821-847.

Nemeth, C. J. 1986. Differential contributions of majority and minority influence. Psychological Review, 93: 23-32.
O’Reilly, C. A., \& Chatman, J. A. 1986. Organizational commitment and psychological attachment: The effects of compliance, identification, and internalization on prosocial behavior. Journal of Applied Psychology, 71: 492-499.

Pache, A.-, \& Santos, F. 2013. Inside the hybrid organization: Selective coupling as a response to competing institutional logics. Academy of Management Journal, 56: 972-1001.

Podolny, J., Khurana, R. A., \& Hill-Popper, M. 2005. Revisiting the meaning of leadership. Journal of Organizational Behavior, 26: 1-31.

Pratt, M., \& Corley, K. 2007. Managing multiple organizational identities: On identity ambiguity, identity conflict, and members' reactions. In C. A. Bartel, S. Blader, \& A. Wrzesniewski (Eds.), Identity and the modern organization: 99-118. Mahwah, NJ: Lawrence Erlbaum Associates.

Pratt, M. G., Rockmann, K. W., \& Kaufmann, J. B. 2006. Constructing professional identity: The role of work and identity learning cycles in the customization of identity among medical residents. Academy of Management Journal, 49: 235-262.

Pratt, M. G. 1998. To be or not to be: Central questions in organizational identification. In Identity in organizations: 171-207. Thousand Oaks, CA: Sage Publications.

Pratt, M. G. 2000. The good, the bad, and the ambivalent: Managing identification among Amway distributors. Administrative Science Quarterly, 45: 456-493.

Pratt, M. G. 2009. For the lack of a boilerplate: Tips on writing up (and reviewing) qualitative research. Academy of Management Journal, 52: 856-862.

Pratt, M. G., \& Foreman, P. O. 2000. Classifying managerial responses to multiple organizational identities. Academy of Management Review, 25: 18-42 [CrossRef:10.2307/259261].

Pratt, M. G., \& Kraatz, M. S. 2009. E pluribus unum: Multiple identities and the organizational self. In L. M. Roberts \& J. E. Dutton (Eds.), Exploring positive identities and organizations: Building a theoretical and Research Foundation: 385-410. New York: Psychology Press.

Pratt, M. G., \& Rafaeli, A. 1997. Organizational dress as a symbol of multilayered social identities. Academy of Management Journal, 40: 862-898.

Reger, R. K., Gustafson, L. T., Demarie, S. M., \& Mullane, J. V. 1994. Reframing the organization: Why implementing total quality is easier said than done. Academy of Management Review, 19: [CrossRef:10. 2307/258939]565.

Rokeach, M. 1973. The nature of human values. New York: The Free Press. 
Rousseau, D. M. 1989. Psychological and implied contracts in organizations. Employee Responsibilities and Rights Journal, 2: 121-139.

Salancik, G. R., \& Pfeffer, J. 1978. A social information processing approach to job attitudes and task design. Administrative Science Quarterly, 23: 224-253.

Schneider, B. 1987. The people make the place. Personnel Psychology, 40: 437-454.

Schweiger, D. M., Sandberg, W. R., \& Ragan, J. W. 1986. Group approaches for improving strategic decision making: A comparative analysis of dialectical inquiry, devil's advocacy, and consensus. Academy of Management Journal, 29: 51-71.

Selznick, P. 1957. Leadership in administration: A sociological interpretation. Evanston, IL: Row Peterson.

Selznick, P. 1994. The moral commonwealth: Social theory and the promise of community. Berkeley, CA: University of California Press.

Seo, M., \& Creed, W. E. D. 2002. Institutional contradictions, praxis, and institutional change: A dialectical perspective. Academy of Management Review, 27: 222-247 [CrossRef:10.2307/4134353].

Shamir, B. 1990. Calculations, values, and identities: The sources of collectivistic work motivation. Human Relations, 43: 313-332.

Sidanius, J., Pratto, F., Van Laar, C., \& Levin, S. 2004. Social dominance theory: Its agenda and method. Political Psychology, 25: 845-880.

Sluss, D. M., \& Ashforth, B. E. 2008. How relational and organizational identification converge: Processes and conditions. Organization Science, 19: 807-823.

Smets, M., Jarzabkowski, P., Burke, G., \& Spee, P. 2014. Reinsurance trading in Lloyd's of London: Balancing conflicting-yet-complementary logics in practice. Academy of Management Journal.

Smircich, L., \& Morgan, G. 1982. Leadership: The management of meaning. Journal of Applied Behavioral Science, 18: 257-273.

Smith, W. K. in press. Dynamic decision making: A model of senior leaders managing strategic paradoxes. Academy of Management Journal.

Smith, W. K., Gonin, M., \& Besharov, M. L. 2013. Managing social-business tensions: A review and research agenda for social enterprise. Business Ethics Quarterly, 23: 407-442.

Smith, W. K., \& Lewis, M. W. 2011. Toward a theory of paradox: A dynamic equilibrium model of organizing. Academy of Management Review, 36: 381-403.

Smith, W. K., \& Tushman, M. L. 2005. Managing strategic contradictions: A top management model for man- aging innovation streams. Organization Science, 16: 522-536.

Sonenshein, S. 2006. Crafting social issues at work. Academy of Management Journal, 49: 1158-1172.

Strauss, A., \& Corbin, J. 1998. Basics of qualitative research (2nd ed.). Thousand Oaks, CA: Sage.

Suddaby, R. 2006. From the Editors: What grounded theory is not. Academy of Management Journal, 49: 633-642.

Suedfeld, P., Tetlock, P., \& Streufert, S. 1992. Conceptual/integrative complexity. In C. Smith, J. Atkinson, D. McClelland \& J. Verof (Eds.), Motivation and personality: Handbook of thematic content analysis: 393-400. Cambridge: Cambridge University Press.

Tetlock, P. E., Kristel, O. V., Elson, S. B., Green, M. C., \& Lerner, J. S. 2000. The psychology of the unthinkable: Taboo trade-offs, forbidden base rates, and heretical counterfactuals. Journal of Personality and Social Psychology, 78: 853-870.

Tetlock, P. E. 1986. A value pluralism model of ideological reasoning. Journal of Personality and Social Psychology, 50: 819-827.

Thompson, J. A., \& Bunderson, J. S. 2003. Violations of principle: Ideological currency in the psychological contract. Academy of Management Review, 28: 571-586.

Tripsas, M., \& Gavetti, G. 2000. Capabilities, cognition and inertia: Evidence from digital imaging. Strategic Management Journal, 18(Summer Special Issues): 119-142.

Voss, Z. G., Cable, D. M., \& Voss, G. B. 2006. Organizational identity and firm performance: What happens when leaders disagree about "who we are?". Organization Science, 17: 741-755.

Whetten, D. A. 2006. Albert and whetten revisited: Strengthening the concept of organizational identity. Journal of Management Inquiry, 15: 219-234.

Wrzesniewski, A. C., Dutton, J. E., \& Debebe, G. 2003. Interpersonal sensemaking and the meaning of work. Research in Organizational Behavior, 25: 93-135.

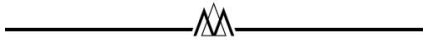

Marya Besharov (mlb363@cornell.edu) is an assistant professor of organizational behavior at the ILR School at Cornell University. She received her doctorate in organizational behavior and sociology from Harvard University. Her research focuses on how organizations manage divergent values, identities, and logics. 
Copyright of Academy of Management Journal is the property of Academy of Management and its content may not be copied or emailed to multiple sites or posted to a listserv without the copyright holder's express written permission. However, users may print, download, or email articles for individual use. 